\title{
9. LATE PALEOCENE AND EARLY EOCENE CALCAREOUS NANNOFOSSILS FROM THREE BOREHOLES IN AN ONSHORE-OFFSHORE TRANSECT FROM NEW JERSEY TO THE ATLANTIC CONTINENTAL RISE ${ }^{1}$
}

\author{
Laurel M. Bybell ${ }^{2}$ and Jean M. Self-Trail ${ }^{2}$
}

\begin{abstract}
Closely spaced, upper Paleocene and lower Eocene samples from three boreholes near Clayton, NJ, at Island Beach, NJ, and at Site 605 on the Atlantic Ocean continental rise were examined for their calcareous nannofossil content. This study documents calcareous nannofossil occurrences in Zones NP9 and NP10 and identifies biostratigraphically useful species, presents unexpected upbasin-downbasin distributional patterns of calcareous nannofossils, discusses the gradual evolutionary transition between two calcareous nannofossil species, and clarifies the relationship between the genera Rhomboaster and Tribrachiatus. One new species, Rhomboaster weii, is described, and two new combinations, Blackites herculesii and Rhomboaster digitalis, are established.
\end{abstract}

\section{INTRODUCTION}

As part of a U.S. Geological Survey-New Jersey Geological Survey joint mapping program begun in 1984, calcareous nannofossils were examined from numerous boreholes in southern New Jersey to understand the geologic history of the region. The Clayton borehole (Fig. 1) contained an apparently continuous and fossiliferous sequence across the Paleocene/Eocene boundary, which was discussed in Gibson et al. (1993) and Bybell and Self-Trail (1995). A comparison between the New Jersey coastal plain and Paleocene/Eocene boundary sediments elsewhere in the Atlantic and Gulf coastal plains of the United States is presented in Gibson and Bybell (1995). As part of the New Jersey Coastal Plain Project, Ocean Drilling Program (ODP) Leg 150X, three boreholes were drilled in New Jersey near the ocean margin at Island Beach, Atlantic City, and Cape May. The borehole at Island Beach (Fig. 1) offered the potential for examining sediments of similar age to those in the Clayton borehole but in a more basinward position (Miller et al., 1994). In addition, Deep Sea Drilling Project (DSDP) Site 605, located oceanward of New Jersey (Fig. 1), also contains upper Paleocene and lower Eocene sediments (van Hinte et al., 1987). It was believed that examination of calcareous nannofossils from these three locations would (1) document any upbasin-downbasin variations in calcareous nannofossil distribution patterns, (2) provide additional documentation of calcareous nannofossil occurrences during this time, particularly for the upper part of Zone NP10, which is absent in the Clayton borehole, (3) continue the documentation of calcareous nannofossil evolution, and (4) provide additional clarification for the taxonomy of the genus Rhomboaster.

\section{MATERIALS AND METHODS}

Calcareous nannofossils were examined from three boreholes that occur in a generally upbasin-downbasin direction from the southern

${ }^{1}$ Miller, K.G., and Snyder, S.W. (Eds.), 1997. Proc. ODP, Sci. Results, 150X: College Station, TX (Ocean Drilling Program).

${ }^{2}$ U.S. Geological Survey, 926 National Center, Reston, VA 20192, U.S.A. lbybell@usgs.gov
New Jersey coastal plain to the offshore continental rise (Fig. 1). First is the Clayton borehole, which was drilled in 1988 by the U.S. Geological Survey near the city of Clayton in Gloucester County, New Jersey, in the Pitman East $7.5^{\prime}$ quadrangle at $39^{\circ} 39^{\prime} \mathrm{N}, 75^{\circ} 6^{\prime} \mathrm{W}$. Second is the Island Beach borehole, which was drilled in 1993 by the U.S. Geological Survey as part of the New Jersey Coastal Plain Drilling Project (ODP Leg 150X) in Ocean County, New Jersey, in the Barnegat Light $7.5^{\prime}$ quadrangle at $39^{\circ} 48^{\prime} \mathrm{N}, 74^{\circ} 6^{\prime} \mathrm{W}$. The third borehole is DSDP Site 605, which was drilled in 1983 on the upper continental rise $\sim 100$ miles southeast of Atlantic City, New Jersey at $38^{\circ} 45^{\prime} \mathrm{N}, 72^{\circ} 37^{\prime} \mathrm{W}$.

Calcareous nannofossil samples for all three boreholes were extracted from the central portion of core segment surfaces (freshly broken where possible) at 2- to 3-ft intervals. Clayton borehole samples were collected in the authors' calcareous nannofossil laboratory as soon as coring was completed and core boxes were transported to Reston, VA. Bybell and Self-Trail (1995) presented the calcareous nannofossil data from the late Paleocene and early Eocene portion of the Clayton borehole, and their occurrence chart is reproduced here as Table 1. Calcareous nannofossil samples from the Island Beach borehole were taken by the authors soon after the cores were transported to Rutgers University in Piscataway, New Jersey. Only samples from Martini's (1971) uppermost Paleocene calcareous nannofossil Zone NP9 and lowermost Eocene Zone NP10 were examined from the Island Beach borehole for this study (Table 2). In 1992, Laurel Bybell sampled the uppermost Paleocene and lowermost Eocene portion of the DSDP Site 605 borehole in the DSDP/ODP repository at Lamont-Doherty Earth Observatory in New York. Calcareous nannofossil occurrences from Site 605 are recorded in Table 3.

Calcareous nannofossil slides were prepared using standard settling techniques and were examined with a Zeiss photomicroscope. In addition, samples with the best preservation and highest abundances of calcareous nannofossils were examined with a JEOL 35 scanning electron microscope (SEM). Use of the SEM provided detailed information on the structure of calcareous nannofossil species that is unavailable with a light microscope.

The graphic correlation method was used to compare fossil data from the individual boreholes. The authors followed the technique of Hood (1996) and directly correlated between the individual sections rather than obtaining a standard reference section. This allowed for the opportunity to identify and refine subtle hiatuses between the sec- 


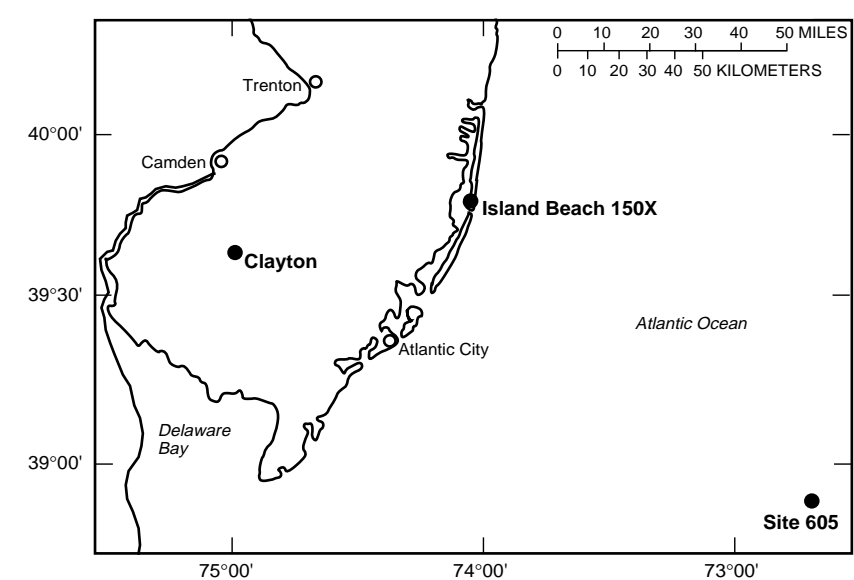

Figure 1. Locations of boreholes (solid circles) that are discussed in text.

tions, to pinpoint reworking of various fossil species, and to identify possible changes in sedimentation rate between the cores.

\section{ZONATION OF THE LATE PALEOCENE AND EARLY EOCENE}

In this study, the biostratigraphic zonation of the strata is based primarily upon the calcareous nannofossil zonation of Martini (1971) and secondarily upon the zonation of Bukry $(1973,1978)$ and Okada and Bukry (1980). The calcareous nannofossil assemblages from the three boreholes typically were sufficient in numbers of specimens, diversity of taxa, and preservational state to allow dating of all samples. However, moving downbasin from Clayton to Island Beach to Site 605, the preservation of calcareous nannofossils decreased significantly through dissolution or recrystallization. There is evidence of reworking in some of the samples, particularly in the Island Beach borehole, and this will be discussed below.

As discussed in Berggren and Aubry (1996), there are five possible positions for the Paleocene/Eocene boundary: (1) the Zone NP9/ NP10 calcareous nannofossil boundary, (2) the P5/P6a planktonic foraminiferal boundary, (3) the base of the Ypresian Stage in Belgium, (4) the base of the Harwich Formation in England, and (5) the $\delta^{13} \mathrm{C}$ spike. Until one of these is officially selected, and because this is primarily a calcareous nannofossil investigation, we will continue with the placement of this boundary at the Zone NP9/NP10 boundary, which is defined by the first appearance datum (FAD) of Rhomboaster bramlettei (Martini, 1971).

Direct comparison of data from this paper with data from elsewhere in New Jersey (Jiang and Wise, 1987; Olsson and Wise, 1987) or at Site 605 (Applegate and Wise, 1987; Lang and Wise, 1987) is complicated somewhat by the fact that they all used the Zone CP8/ CP9 boundary of Okada and Bukry (1980) to define the Paleocene/ Eocene boundary. Most correlations between the zonation of Martini (1971) and that of Okada and Bukry (1980) place the Zone CP8/CP9 boundary and the Zone NP9/NP10 boundary at the same interval (Okada and Bukry, 1980; Berggren et al., 1985; Perch-Nielsen, 1985). The FADs of both Rhomboaster contortus and Discoaster diastypus define the base of Zone CP9 (Bukry, 1973, 1978). Romein (1979), Perch-Nielsen (1985), Pospichal and Wise (1990), and Bralower and Mutterlose (1995) recognized that the FAD of $R$. contortus occurs above the base of $R$. bramlettei. Lacking reliable occurrences of the species D. diastypus, which Pospichal and Wise (1990) and Bralower and Mutterlose (1995) assumed had its FAD near the FAD of $R$. bramlettei, they substituted the FAD of $R$. bramlettei to define the base of Zone CP9. Gibson et al. (1993), Bybell and Self-Trail (1995), and Angori and Monechi (1996) recognized that the FADs of
$R$. contortus and D. diastypus lie well above the FAD of $R$. bramlettei, and they placed the Zone CP8/CP9 boundary within Zone NP10. Data from the current study support this placement. Berggren and Aubry (1996, fig. 13) placed the Zone CP8/CP9 boundary in the lower part of Zone NP10.

The following calcareous nannofossil species are useful in dating upper Paleocene and lower Eocene sediments. The relative positions of FADs and last appearance datums (LADs) are indicated below. Zonal markers for the Martini NP zones are indicated with an *, and a \# indicates a zonal marker for the Bukry CP zones. The remaining species have been found by the authors to be biostratigraphically useful, particularly in the Gulf and Atlantic Coastal Plains.

FAD *\#Discoaster lodoensis $=$ base of Zone NP12, base Zone CP10

FAD Discoaster binodosus $=$ within Zone NP11

LAD *\#Rhomboaster contortus $=$ top of Zone NP10, top Subzone $\mathrm{CP} 9 \mathrm{a}$

FAD Rhomboaster orthostylus = upper Zone NP10

FAD Rhomboaster contortus = mid- or upper Zone NP10, base Subzone CP9a

FAD \#Discoaster diastypus = mid- or upper Zone NP10, base Subzone CP9a

LAD Fasciculithus spp. = lower Zone NP10

FAD * Rhomboaster bramlette $i=$ base of Zone NP10

FAD Rhomboaster spineus $=$ uppermost Zone NP9

FAD Transversopontis pulcher sensu ampl. = within upper Zone NP9

FAD Discoaster mediosus = within upper Zone NP9

FAD Toweius occultatus $=$ within upper Zone NP9

FAD \#Campylosphaera dela = within upper Zone NP9, base Subzone CP8b (includes C. eodela)

FAD Lophodolithus nascens $=$ within upper Zone NP9

FAD Toweius callosus $=$ within Zone NP9

FAD Discoaster lenticularis $=$ near base of Zone NP9

FAD *\#Discoaster multiradiatus = base of Zone NP9, base Subzone CP8a

Figure 2 shows calcareous nannofossil species that are biostratigraphically useful in New Jersey and the North Atlantic. It is to be expected that many of these species will prove to be useful in other regions.

\section{RESULTS Clayton Borehole}

Bybell and Self-Trail (1995) examined calcareous nannofossils from 39 samples in the Clayton borehole from 348.5 to $292.0 \mathrm{ft}$ (106.2-89.0 m). Sixteen samples were from the upper Paleocene Vincentown Formation, and 23 samples were from the upper Paleocene and lower Eocene Manasquan Formation (Table 1). The lowest Zone NP9 sediments occur within the Vincentown Formation at $348.5 \mathrm{ft}(106.2 \mathrm{~m})$. The lower part of Zone NP9 is presumed to be missing in the Clayton borehole because the lowest Zone NP9 sample at $348.5 \mathrm{ft}(106.2 \mathrm{~m})$ contains both Campylosphaera dela and Lophodolithus nascens, which have their FADs in the upper half of Zone NP9 (Perch-Nielsen, 1985). Laurel M. Bybell (unpubl. data) finds that $C$. dela and L. nascens are consistently absent from the lower part of Zone NP9 in the Gulf and Atlantic Coastal Plains. This does contrast with a lower position for the FAD of the genus Campylosphaera found by Bralower and Mutterlose (1995) at ODP Site 865 in the Pacific. A dissolution zone in the Vincentown Formation from 345.2 to $329.0 \mathrm{ft}(105.2-100.3 \mathrm{~m})$ has resulted in a notable decrease in calcareous nannofossil and foraminiferal species diversity (Gibson et al., 1993). Similar dissolution intervals have been reported from the upper part of Zone NP9 in many locations: Aubry et al. (1996) 
from DSDP Sites 549 and 550, Angori and Monechi (1996) from the Caravaca section in Spain, and Thomas (1996) from Sites 525 and 527. We also find a dissolution interval in the Island Beach borehole (see below). The position of these dissolution intervals may not be consistent with regard to the benthic foraminiferal extinction event, which now appears to have been synchronous around the world (Thomas, 1996), and the Zone NP9/NP10 boundary. It is unclear whether these discrepancies in position of the dissolution interval are real or only apparent due to minor unconformities.

Approximately $10 \mathrm{ft}(3 \mathrm{~m})$ above the top of the dissolution zone in the Clayton borehole, between 320.5 and $316.9 \mathrm{ft}$ (97.7 and 96.6 $\mathrm{m})$, there is a gradual lithologic change from the Vincentown Formation to the Manasquan Formation. This 4-ft transition zone corresponds to the worldwide late Paleocene climatic event and contains the benthic foraminiferal extinction, an increase in planktonic foraminifers, a lithologic change from sand to clay, and a change in clay mineral suites from primarily illite/smectite to primarily kaolinite (Gibson et al., 1993). Because of the proximity of the dissolution interval and the climatic event in both the Clayton and Island Beach boreholes, it seems likely that the two events are related.

There may be a short hiatus between the Vincentown and Manasquan Formations, as evidenced by the increase in calcareous nannofossil FADs and LADs to eight species in this interval (Table 1). Farther offshore, a much longer hiatus occurs at this same position in both the Island Beach and Site 605 boreholes (see discussion below).

In the Clayton borehole, the Zone NP9/NP10 boundary, which occurs within the Manasquan Formation between samples at 306.9 and $306.5 \mathrm{ft}(93.5$ and $93.4 \mathrm{~m})$, represents continuous deposition as can be seen in the graphic correlation presented on Figures 3 and 4. Only $14.5 \mathrm{ft}(4.4 \mathrm{~m})$ of lower Zone NP10 are preserved in the Clayton borehole, and these sediments are unconformably overlain by the middle Eocene Shark River Formation at $290 \mathrm{ft}$ (88.4 m; Figs. 3, 4).

There is no evidence for reworking of material in the Clayton borehole. However, several species do appear to be responding to outside environmental controls. The upper range of Hornibrookina arca is truncated in the Clayton borehole in comparison to its range in the Island Beach borehole, where it extends above the FAD of Rhomboaster contortus (Tables 1, 2; Fig. 3). At Site 605, H. arca also has a truncated upper range, and it disappears before the first appearance of $R$. contortus (Table 3). Hornibrookina arca is never consistently present in a sedimentary sequence, and, when it is present, it often occurs in large numbers. Paleoenvironmental or paleoecological controls such as water depth, salinity, or temperature may be responsible for the fluctuation in this species' range.

\section{Island Beach Borehole}

Thirty-five samples were examined in the Island Beach borehole from 1121.4 to $1018.9 \mathrm{ft}$ (341.8-310.6 m). Eleven samples were from the Vincentown Formation, and 24 samples were from the Manasquan Formation (Table 2). Discoaster multiradiatus (FAD defines the base of Zone NP9) first occurs within the Vincentown Formation at $1121.4 \mathrm{ft}(341.8 \mathrm{~m})$ in the Island Beach borehole. The authors have observed the co-occurrence of $D$. multiradiatus and $H$. riedelii only in lower Zone NP9 sediments from Virginia, and Bralower and Mutterlose (1995) found a similar distribution at Site 865. Heliolithus universus also appears to occur no higher than the lower part of Zone NP9. The lower three Zone NP9 samples from 1121.4 to $1111.8 \mathrm{ft}$ (341.8-338.9 m) can thus be restricted to the lower part of Zone NP9 based on the presence of D. multiradiatus, Heliolithus riedelii, and Heliolithus universus. Campylosphaera dela and Lophodolithus nascens are absent from this interval. Portions of the upper half of Zone NP9 are present in the Island Beach borehole from 1104.9 to $1077.8 \mathrm{ft}$ (336.8-328.5 m), based on the presence of Lophodolithus nascens and Campylosphaera dela.

There is a dissolution interval in the Island Beach borehole at the same position in Zone NP9 as in the Clayton borehole (top is $\sim 10 \mathrm{ft}$ below the Vincentown/Manasquan formational contact), and preservation and diversity of calcareous nannofossil species is noticeably reduced between 1104.9 and $1089.4 \mathrm{ft}$ (336.8 and $332.0 \mathrm{~m}$; Table 2).

As in the Clayton borehole, at Island Beach there is a lithologic change at the Vincentown/Manasquan contact (1076 ft [371 m]) from clay below to silty clay above the contact, and the contact is disconformable between the two formations (Miller et al., 1994). The lower part of the Manasquan Formation (uppermost part of Zone NP9 in the Clayton borehole) is missing in the Island Beach borehole (Figs. 3, 5), and the basal Manasquan sample at $1075.8 \mathrm{ft}$ (327.9 m) is in Zone NP10. As a result, there are no sediments at Island Beach that are equivalent to the lowest Manasquan Formation in the Clayton borehole (319.4-306.9 ft [97.4-93.5 m]; Table 1). As confirmed by Aubry et al. (1996), the authors have long recognized the abundance of minor unconformities in marine sedimentary sequences, both in the nearshore and offshore regimes. These previously unrecognized unconformities are now being identified because of recent studies using closely spaced sampling intervals combined with a large number of documented calcareous nannofossil FADs and LADs.

There is reworking of Vincentown material up into much of the Manasquan Formation at Island Beach, and this is most noticeable in the interval from the basal Manasquan sample at $1075.8 \mathrm{ft}(327.9 \mathrm{~m})$ up to $1059.9 \mathrm{ft}(323.1 \mathrm{~m})$. Pak et al., Chapter 23, this volume, find evidence for reworking of benthic foraminifers within this interval (1075-1065 ft [327.7-324.6 m]). Five calcareous nannofossil species-Biantholithus astralis, Fasciculithus alanii, Fasciculithus schaubii, Scapholithus apertus, and Toweius eminens var. tovae, which have their LADs in the upper part of Zone NP9 (Bybell and Self-Trail, 1995) — are reworked into Zone NP10 in the lower part of the Manasquan Formation in the Island Beach borehole (Table 2; Figs. 3, 5). Bralower and Mutterlose (1995) also found $F$. alanii to be absent from Zone NP10, as well as F. schaubii, except for a rare occurrence in the lowest Zone NP10 in Core 865C. The continuance of large numbers of Toweius eminens var. eminens into Zone NP10 in the Island Beach borehole and at Site 605, when it occurs no higher than Zone NP9 in the Clayton borehole, is believed to be the result of paleoecological or paleoenvironmental preferences for this species, rather than reworking.

Whereas the Clayton borehole only had $14.5 \mathrm{ft}$ (4.4 m) of Zone NP10 sediments, the Island Beach borehole has $57 \mathrm{ft}(17.4 \mathrm{~m})$ of Zone NP10 sediments, and both the lower and upper parts of the zone are represented. However, most of the Island Beach borehole is what normally would be considered to be the lower part of Zone NP10 because Rhomboaster contortus (FAD in upper half of Zone NP10) is only present in the upper two Zone NP10 samples at $1020.9 \mathrm{ft}(311.2$ $\mathrm{m})$ and $1018.9 \mathrm{ft}(310.6 \mathrm{~m})$, and Rhomboaster orthostylus is only present in the uppermost Zone NP10 sample at $1018.9 \mathrm{ft}$ (310.6 m). A sample from $1016.9 \mathrm{ft}(310.0 \mathrm{~m})$ is in Zone NP11. A similar placement for the FADs of $R$. contortus and $R$. orthostylus occurs at Site 605 (see below). Angori and Monechi (1996) reported the FAD of $R$. contortus near the middle of Zone NP10 at Caravaca, as did Wei and Zhong (1996) and Aubry et al. (1996) at DSDP Site 550. However, at DSDP Site 690B, the FADs of $R$. contortus and $R$. orthostylus occur much nearer the top of Zone NP10 in what is presumed to be a discontinuous section (Aubry et al., 1996; Wei and Zhong, 1996). If the FADs of $R$. contortus and $R$. orthostylus actually do occur in the middle of Zone NP10, then there must be an unconformity at Island Beach that represents some of upper Zone NP10. Such a hiatus, however, was not detected using graphic correlation (Fig. 5).

\section{DSDP Site 605 Borehole}

Lang and Wise (1987) examined 9 samples from Zone NP9 at Site 605 from 1973.4 to $1835.6 \mathrm{ft}(601.5-559.5 \mathrm{~m})$, and Applegate and Wise (1987) examined 2 samples from Zone NP9 at Site 605 from 1855.3 to $1835.6 \mathrm{ft}(565.5-559.5 \mathrm{~m})$ and 5 samples from Zone NP10 from 1830.7 to $1809.0 \mathrm{ft}(558.0-551.4 \mathrm{~m})$. 
Table 1. Calcareous nannofossil occurrences in Zones NP9 and NP10 in the Clayton borehole, NJ.

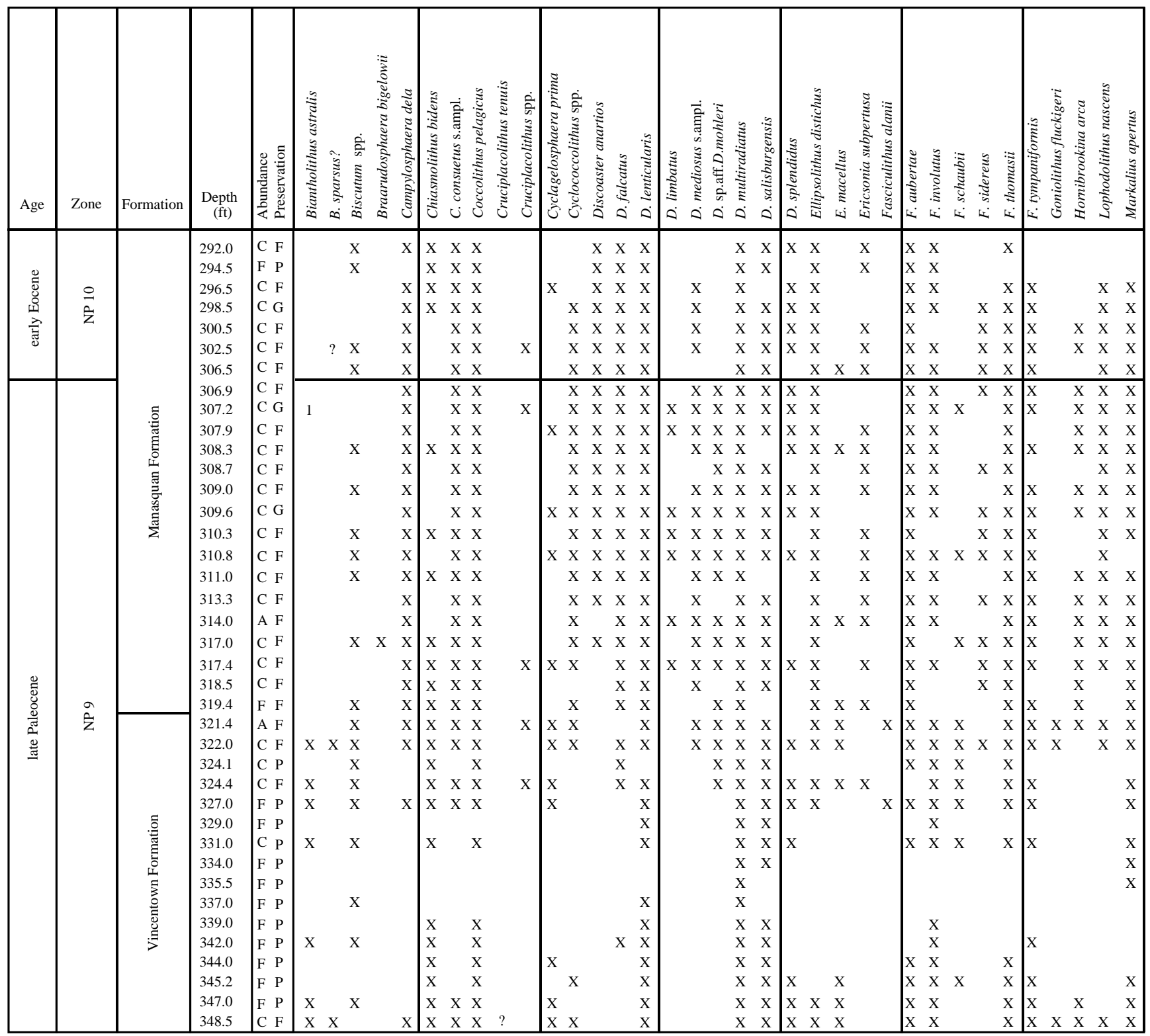

Notes: $\mathrm{A}=$ abundant, or greater than 10 specimens per field of view at $500 \times ; \mathrm{C}=$ common, or 1 to 10 specimens per field of view at $500 \times$; $\mathrm{F}=$ frequent, or 1 specimen per $2-10$ fields of view at $500 \times ; \mathrm{R}=$ rare, or 1 specimen in greater than 10 fields of view at $500 \times . \mathrm{G}=$ good, $\mathrm{F}=$ fair, $\mathrm{P}=$ poor. See Figure 1 for location of boreholes. $\mathrm{B}=$ sample barren of calcareous nacareous nannofossils; $1=$ only one specimen observed in entire sample; $2=$ only two specimens observed in entire sample; ?=possible occurrence.

For the current study, 64 samples were examined from the DSDP Site 605 borehole between 1894.7 and $1751.6 \mathrm{ft}(577.5$ and $533.9 \mathrm{~m})$ : 21 samples were from Zone NP9, 33 from Zone NP10, 5 from Zone NP11, and 5 that are questionably from Zone NP12 (Table 3). Only the upper part of Zone NP9 was examined at Site 605, and it is unclear what part of Zone NP9 is present in the unexamined material between 1973.4 and $1894.7 \mathrm{ft}(601.5$ and $577.5 \mathrm{~m})$. The lowest sample examined at $1894.7 \mathrm{ft}(577.5 \mathrm{~m})$ is in the upper part of Zone NP9 because Campylosphaera dela, Lophodolithus nascens, and Fasciculithus alanii are present in this sample (FADs in the upper part of Zone NP9). Unlike at the Clayton and Island Beach boreholes, there is no evidence of a dissolution interval in the upper part of Zone NP9 at Site 605, although this may be present farther down in the unsampled portion of Zone NP9.

The FADs of Rhomboaster bramlettei (FAD defines the base of Zone NP10), Toweius occultatus, and Transversopontis pulcher (both FADs occur within Zone NP9 at the base of the Manasquan Formation) are present at $1849.7 \mathrm{ft}(563.8 \mathrm{~m})$ in the Site 605 borehole (Table 3). Thus, the upper portion of Zone NP9 (the Zone NP9 part of the Manasquan Formation in the Clayton borehole) also is missing at Site 605 , as it was in the Island Beach borehole, and there is an unconformity at $1850.0 \mathrm{ft}(563.9 \mathrm{~m})$ at Site 605 (Figs. 4, 5). Ellen Thomas (pers. comm., 1996) agrees that the upper part of Zone NP9 is missing at Site 605 because the benthic foraminiferal extinction event, which normally occurs within Zone NP9, is between 1850 and $1849.4 \mathrm{ft}(563.9$ and $563.7 \mathrm{~m})$ at Site 605 , or at the Zone NP9/NP10 boundary.

Our placement of the base of Zone NP10 at $1849.7 \mathrm{ft}(563.8 \mathrm{~m})$ is $19 \mathrm{ft}$ lower than the placement by Lang and Wise (1987) and Applegate and Wise (1987) at $1830.7 \mathrm{ft}(558.0 \mathrm{~m})$. However, this discrepancy is entirely a result of their greater sampling interval. Van Hinte et al. (1987, p. 387) in the Site 605 stratigraphic sections placed the 
Table 1 (continued).

\begin{tabular}{|c|c|c|c|c|c|c|c|c|c|c|c|c|c|c|c|c|c|c|c|c|}
\hline Age & Zone & Formation & $\begin{array}{l}\text { Depth } \\
\text { (ft) }\end{array}$ & 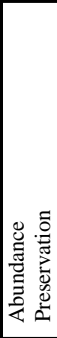 & 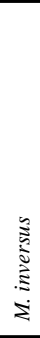 & 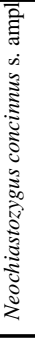 & 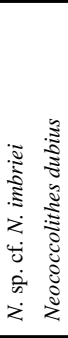 & 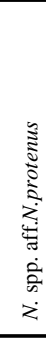 & 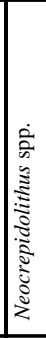 & 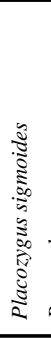 & 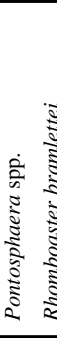 & 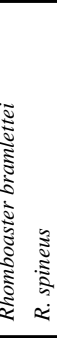 & 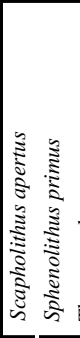 & 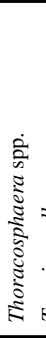 & 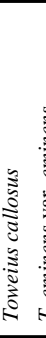 & & 预 & 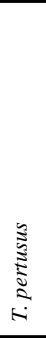 & 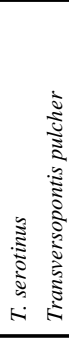 & 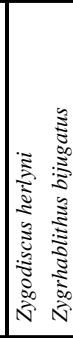 \\
\hline 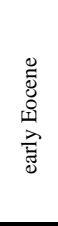 & $\begin{array}{l}\stackrel{\varrho}{\varrho} \\
\text { z̀ }\end{array}$ & \multirow[b]{2}{*}{ 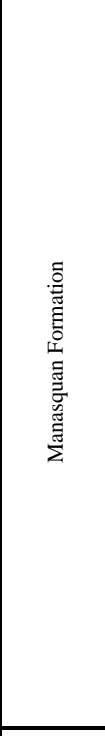 } & $\begin{array}{l}292.0 \\
294.5 \\
296.5 \\
298.5 \\
300.5 \\
302.5 \\
306.5 \\
\end{array}$ & $\begin{array}{lll}\text { C } & \text { F } \\
\text { F } & \text { P } \\
\text { C } & \text { F } \\
\text { C } & \text { G } \\
\text { C } & \text { F } \\
\text { C } & \text { F } \\
\text { C } & \text { F } \\
\end{array}$ & $\begin{array}{l}X \\
X \\
X \\
X \\
X \\
X \\
X\end{array}$ & $\begin{array}{l}X \\
X \\
X \\
X \\
X \\
X \\
X \\
\end{array}$ & $\begin{array}{l}X \\
X \\
X \\
X \\
\end{array}$ & $\begin{array}{l}\mathrm{X} \\
\mathrm{X} \\
\mathrm{X} \\
\mathrm{X} \\
\end{array}$ & & $\begin{array}{l}\mathrm{X} \\
\mathrm{X} \\
\mathrm{X} \\
\mathrm{X} \\
\mathrm{X}\end{array}$ & $\begin{array}{rr} & \mathrm{X} \\
& \mathrm{X} \\
\mathrm{X} \\
\mathrm{X} \\
& \mathrm{X} \\
\mathrm{X} & \mathrm{X} \\
& \mathrm{X} \\
\end{array}$ & $\begin{array}{ll}X & \\
X & \\
X & \\
X & X \\
X & X \\
X & X \\
X & X \\
\end{array}$ & $\begin{array}{l}x \\
X\end{array}$ & $\begin{array}{l}\mathrm{X} \\
\mathrm{X} \\
\mathrm{X} \\
\mathrm{X} \\
\mathrm{X} \\
\mathrm{X}\end{array}$ & $\begin{array}{l}X \\
X \\
X \\
X\end{array}$ & & $\begin{array}{l}X \\
X \\
X \\
X \\
X\end{array}$ & $\begin{array}{l}X \\
X \\
X \\
X \\
X \\
X \\
X \\
\end{array}$ & $\begin{array}{cc}\mathrm{X} & \mathrm{X} \\
\mathrm{X} & \\
\mathrm{X} & \mathrm{X} \\
& \mathrm{X} \\
\mathrm{X} & \mathrm{X} \\
& \mathrm{X} \\
& \mathrm{X} \\
\end{array}$ & $\begin{array}{l}x \\
x \\
x \\
x \\
\end{array}$ \\
\hline \multirow{2}{*}{ 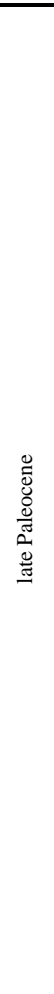 } & \multirow{2}{*}{$\hat{z}$} & & $\begin{array}{l}306.9 \\
307.2 \\
307.9 \\
308.3 \\
308.7 \\
309.0 \\
309.6 \\
310.3 \\
310.8 \\
311.0 \\
313.3 \\
314.0 \\
317.0 \\
317.4 \\
318.5 \\
319.4\end{array}$ & $\begin{array}{ll}\mathrm{C} & \text { F } \\
\mathrm{C} & \mathrm{G} \\
\mathrm{C} & \mathrm{F} \\
\mathrm{C} & \mathrm{F} \\
\mathrm{C} & \mathrm{F} \\
\mathrm{C} & \mathrm{F} \\
\mathrm{C} & \mathrm{G} \\
\mathrm{C} & \mathrm{F} \\
\mathrm{C} & \mathrm{F} \\
\mathrm{C} & \mathrm{F} \\
\mathrm{C} & \mathrm{F} \\
\mathrm{A} & \mathrm{F} \\
\mathrm{C} & \mathrm{F} \\
\mathrm{C} & \mathrm{F} \\
\mathrm{C} & \mathrm{F} \\
\mathrm{F} & \mathrm{F}\end{array}$ & $\begin{array}{l}X \\
X \\
X \\
X \\
X\end{array}$ & $\begin{array}{l}X \\
X \\
X \\
X \\
X \\
X \\
X \\
X \\
X \\
X \\
X \\
X \\
X \\
X \\
X \\
X \\
X \\
X\end{array}$ & $\begin{array}{l}\mathrm{X} \\
\mathrm{X} \\
\mathrm{X} \\
\mathrm{X} \\
\mathrm{X} \\
\mathrm{X} \\
\mathrm{X} \\
\mathrm{X} \\
\mathrm{X} \\
\mathrm{X} \\
\mathrm{X} \\
\mathrm{X}\end{array}$ & $\begin{array}{l}X \\
X \\
X \\
X \\
X \\
X \\
X \\
X \\
X \\
X \\
X \\
X \\
X \\
X \\
X \\
X\end{array}$ & $\mathrm{x}$ & $\begin{array}{l}\mathrm{X} \\
\mathrm{X} \\
\mathrm{X} \\
\mathrm{X} \\
\mathrm{X} \\
\mathrm{X} \\
\mathrm{X} \\
\mathrm{X} \\
\mathrm{X} \\
\mathrm{X} \\
\mathrm{X} \\
\mathrm{X} \\
\mathrm{X} \\
\mathrm{X} \\
\mathrm{X}\end{array}$ & $\begin{array}{l}X \\
X\end{array}$ & $\begin{array}{l}\mathrm{X} \\
\mathrm{X} \\
\mathrm{X}\end{array}$ & $\begin{array}{ll} & \mathrm{X} \\
1 & \\
& \end{array}$ & $\begin{array}{l}\mathrm{X} \\
\mathrm{X} \\
\\
\mathrm{X} \\
\mathrm{X} \\
\mathrm{X} \\
\mathrm{X} \\
\mathrm{X} \\
\mathrm{X} \\
\mathrm{X} \\
\mathrm{X} \\
\mathrm{X} \\
\mathrm{X} \\
\mathrm{X} \\
\mathrm{X}\end{array}$ & $\begin{array}{l}X \\
X \\
X \\
X \\
X \\
X\end{array}$ & & $\begin{array}{l}\mathrm{X} \\
\mathrm{X} \\
\mathrm{X} \\
\mathrm{X} \\
\mathrm{X} \\
\mathrm{X} \\
\mathrm{X} \\
\mathrm{X} \\
\mathrm{X} \\
\mathrm{X} \\
\mathrm{X} \\
\mathrm{X} \\
\mathrm{X} \\
\mathrm{X} \\
\mathrm{X} \\
\mathrm{X}\end{array}$ & $\begin{array}{l}X \\
X \\
X \\
X \\
X \\
X \\
X \\
X \\
X \\
X \\
X \\
X \\
X \\
X \\
X \\
X\end{array}$ & $\begin{array}{cc} & \mathrm{X} \\
& \mathrm{X} \\
\mathrm{X} & \mathrm{X} \\
& \mathrm{X} \\
& \mathrm{X} \\
& \mathrm{X} \\
\mathrm{X} & \mathrm{X} \\
& \mathrm{X} \\
\mathrm{X} & \mathrm{X} \\
& \mathrm{X} \\
& \mathrm{X} \\
\mathrm{X} & \mathrm{X} \\
\mathrm{X} & \mathrm{X} \\
\mathrm{X} & \mathrm{X} \\
\mathrm{X} & \mathrm{X} \\
& \mathrm{X}\end{array}$ & $\begin{array}{l}x \\
x \\
x \\
x \\
x \\
x \\
x \\
x \\
x \\
x \\
x \\
x \\
x \\
x \\
x\end{array}$ \\
\hline & & 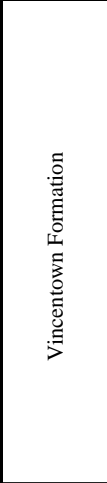 & $\begin{array}{l}321.4 \\
322.0 \\
324.1 \\
324.4 \\
327.0 \\
329.0 \\
331.0 \\
334.0 \\
335.5 \\
337.0 \\
339.0 \\
342.0 \\
344.0 \\
345.2 \\
347.0 \\
348.5\end{array}$ & $\begin{array}{lll}\text { A } & \text { F } \\
\text { C } & \text { F } \\
\text { C } & \text { P } \\
\text { C } & \text { F } \\
\text { F } & \text { P } \\
\text { F } & \text { P } \\
\text { C } & \text { P } \\
\text { F } & \text { P } \\
\text { F } & \text { P } \\
\text { F } & \text { P } \\
\text { F } & \text { P } \\
\text { F } & \text { P } \\
\text { F } & \text { P } \\
\text { F } & \text { P } \\
\text { F } & \text { P } \\
\text { C } & \text { F }\end{array}$ & $\begin{array}{l}X \\
X\end{array}$ & $\begin{array}{l}X \\
X\end{array}$ & & $\begin{array}{l}X \\
X\end{array}$ & $\begin{array}{l}x \\
x \\
x\end{array}$ & $\begin{array}{l}X \\
X \\
X\end{array}$ & & & $\mid \begin{array}{ll}x & \\
x & x \\
x & \end{array}$ & $\begin{array}{l}\mathrm{x} \\
\mathrm{x}\end{array}$ & $\begin{array}{ll}\mathrm{X} & \mathrm{X} \\
\mathrm{X} & \mathrm{X} \\
\mathrm{X} & \\
\mathrm{X} & \searrow \\
\mathrm{X} & \mathrm{X}\end{array}$ & $\begin{array}{l}x \\
X \\
x\end{array}$ & & $\begin{array}{l}X \\
X \\
X \\
X \\
X \\
\\
X\end{array}$ & $\begin{array}{l}\mathrm{X} \\
\mathrm{X}\end{array}$ & $\begin{array}{l}x \\
x \\
x\end{array}$ \\
\hline
\end{tabular}

Paleocene/Eocene boundary at $1850.0 \mathrm{ft}(563.9 \mathrm{~m})$ or almost exactly where we place the boundary. Photographs of the Site 605 core at this interval (van Hinte et al., 1987, p. 401) show a lithologic change at this same depth (1850.0 ft or $563.9 \mathrm{~m})$. Olsson and Wise (1987) also placed the Paleocene/Eocene boundary at this same lithologic contact at Site 605, which is the downdip facies equivalent of the Vincentown/Manasquan formational boundary.

There is no evidence of reworking of Zone NP9 sediments into Zone NP10 at Site 605, as was found in the Island Beach borehole, and lower Zone NP10 calcareous nannofossil occurrences at Site 605 and in the Clayton borehole are quite similar (Tables 1 and 3). Site 605 has $43 \mathrm{ft}(13.1 \mathrm{~m})$ of Zone NP10 sediments, Island Beach has 57 $\mathrm{ft}(17.4 \mathrm{~m})$, and the Clayton borehole only has $14.5 \mathrm{ft}(4.4 \mathrm{~m})$. Both Rhomboaster contortus and $R$. orthostylus occur in Zone NP10 sediments at Site 605, but as in the Island Beach borehole, they are only in the very upper part of this zone, which may be indicative of a small unconformity. Rhomboaster contortus, for example, is confined to the upper $12 \mathrm{ft}(3.7 \mathrm{~m})$, and $R$. orthostylus is only present in the upper $2 \mathrm{ft}(0.6 \mathrm{~m})$ of Zone NP10.

\section{DISCUSSION}

\section{Onshore/Offshore Patterns}

One goal of this study was to document upbasin-downbasin variations in calcareous nannofossil distribution patterns. During the late Paleocene and early Eocene, sediments at Clayton (the farthest upbasin position) were being deposited in middle neritic depths (T.G. Gibson, pers. comm., 1996) with deepening of waters offshore to lower bathyal at Site 605 (E. Thomas, pers. comm., 1996). At the Clayton borehole (farthest upbasin position), the base of Zone NP10 occurs at $\sim 190 \mathrm{ft}(58 \mathrm{~m})$ below sea level. Downdip at Island Beach, the base of Zone NP10 occurs at $1064 \mathrm{ft}$ (324 m) below sea level, and at Site 605 it is at $9048 \mathrm{ft}(2758 \mathrm{~m})$ below sea level. The base of Zone NP10 drops $874 \mathrm{ft}(266 \mathrm{~m})$ from Clayton to Island Beach in a 20-mile downbasin transect or $\sim 44 \mathrm{ft}$ per mile. Between Island Beach and Site 605, the base of Zone NP10 drops $7984 \mathrm{ft}(2434 \mathrm{~m})$ in a 110-mile downbasin transect or $73 \mathrm{ft}$ per mile. However, it is unlikely that these elevations for the base of Zone NP10 reflect relative positions 
Table 2. Calcareous nannofossil occurrences in Zones NP9 and NP10 in the Island Beach borehole, NJ.

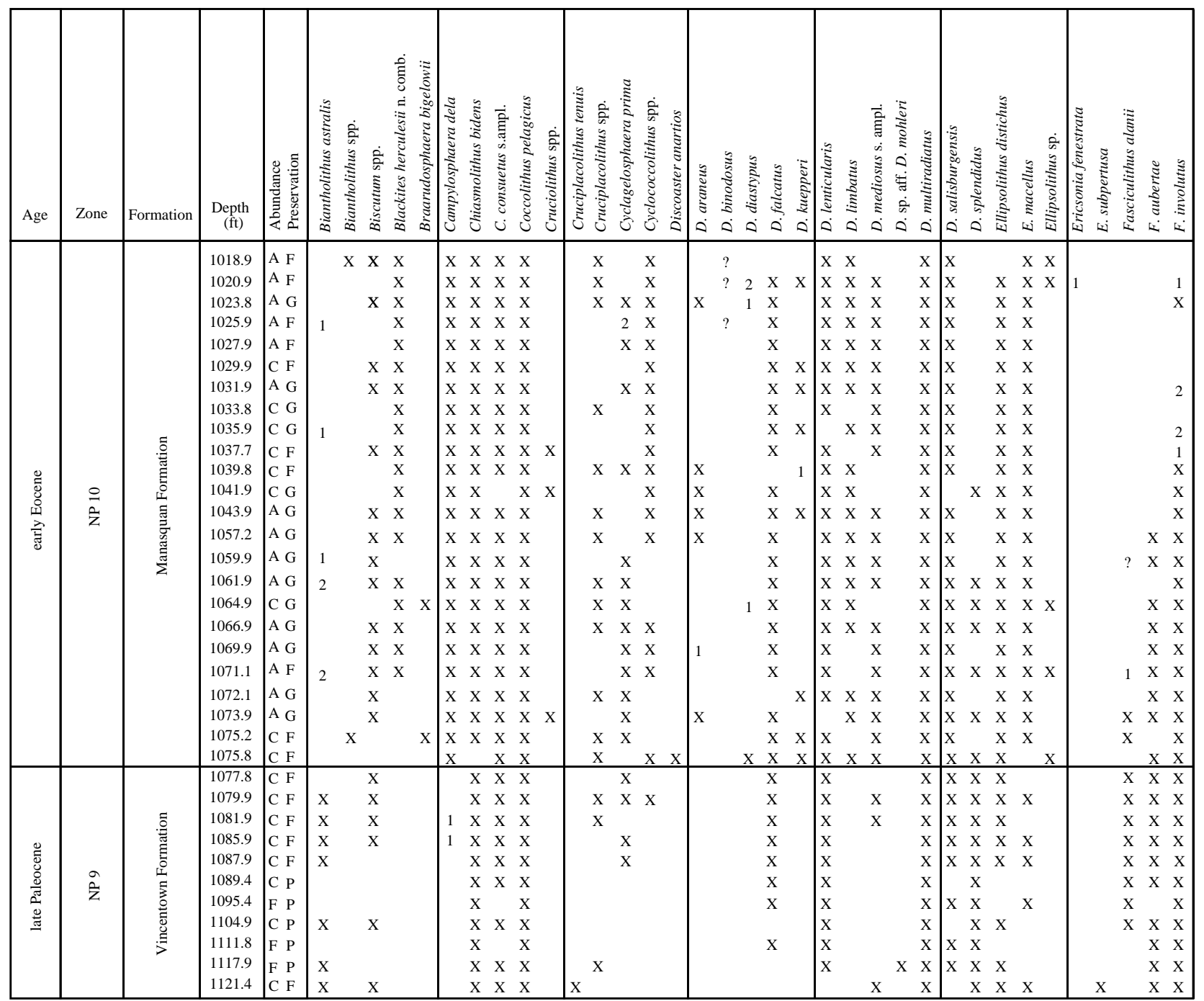

Notes: See Figure 1 for location of borehole and Table 1 for symbol definitions.

during deposition because there has been renewed tectonic uplift in the Piedmont area of New Jersey since the early Eocene, as well as sediment loading, sediment compaction, and flexure.

In the three boreholes studied, there are noticeable preservational differences in the calcareous nannofossils. The best preservation occurs in the Clayton borehole, there is increased dissolution at Island Beach, and there is a significant amount of recrystallization at Site 605. These preservational differences do not appear to be sufficient to affect calcareous nannofossil diversity, which does not vary significantly among the three boreholes.

However, there are some unexpected distributional differences among calcareous nannofossil species in the three boreholes. For example, members of the family Braarudosphaeraceae, which is represented in the study area by the two genera Braarudosphaera and $\mathrm{Mi}$ crantholithus, have been reported principally from nearshore and hemipelagic deposits during the Paleogene (Bybell and Gartner, 1972; Perch-Nielsen, 1985; Siesser et al., 1992). One would therefore expect the greatest numbers of these genera to occur in the most nearshore position at Clayton. This does not occur, and in Zone NP10 the greatest numbers of both Braarudosphaera and Micrantholithus occur at Site 605. In fact, Micrantholithus is completely absent from both Island Beach and Clayton and from five other boreholes near
Clayton (Bybell and Self-Trail, 1995), while Braarudosphaera has a very sporadic occurrence in these more nearshore locations. Several deep-water deposits with braarudosphaerid concentrations have been reported, but these are primarily from the Oligocene (see Siesser et al., 1992 for a list of pertinent references) and are suspected to reflect unusual oceanographic conditions. No significant oceanographic differences have been documented to date in the $\sim 135$ miles between Clayton and Site 605.

Bukry (1971) reported that braarudosphaerids are poorly resistant to dissolution. However, preservational differences in the study area offer no easy solution to braarudosphaerid distribution because the best preserved samples at Clayton have few braarudosphaerids, the poorly preserved samples (from dissolution) at Island Beach also have few braarudosphaerids, and the poorly preserved samples at Site 605 (from recrystallization) have numerous braarudosphaerids.

To complicate the picture further, conditions that control braarudosphaerid distribution (whatever they may be) appear to be related to the latest Paleocene-earliest Eocene climatic event, but only in offshore locations. At Clayton, there are no representatives of Micrantholithus or Braarudosphaera in Zones NP9 or NP10, except for one sample in Zone NP9 that has rare Braarudosphaera bigelowii. At Island Beach, there are no representatives of Micrantholithus in either 
Table 2 (continued).

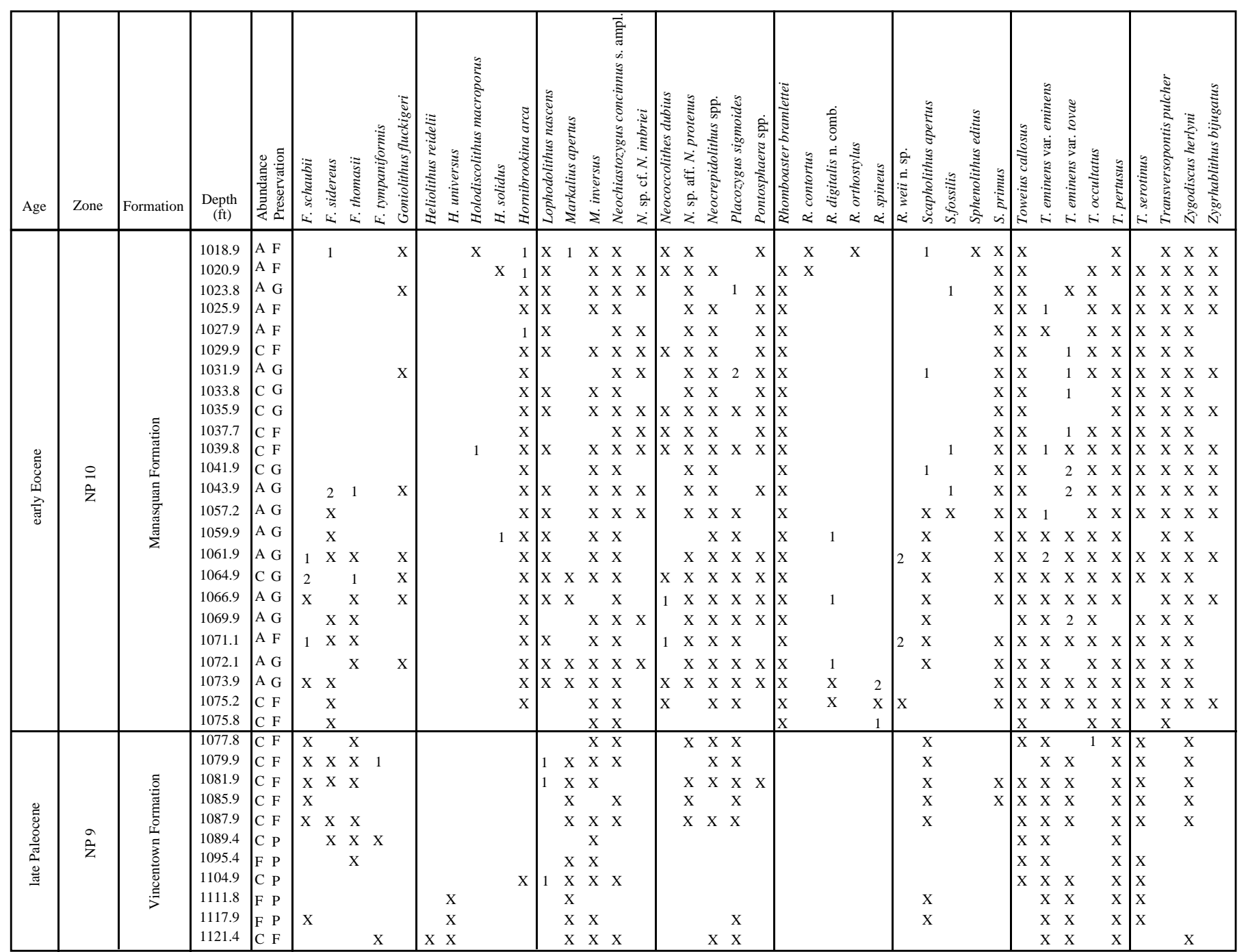

zone, and there are only a few rare B. bigelowii specimens in Zone NP10. At Site 605, although Micrantholithus and Braarudosphaera are absent from Zone NP9, they occur consistently in Zone NP10. Keeping in mind that the uppermost part of Zone NP9 is missing at Site 605 , it seems reasonable to suggest that after the climatic event, conditions changed offshore and became favorable for braarudosphaerids.

Holococcoliths are another group of calcareous nannofossils that is believed to be restricted to relatively shallow seas and in samples with good preservation (Perch-Nielsen, 1985). Zygrhablithus bijugatus, a holococcolith, occurs most consistently at Site 605 (the borehole with the worst preservation), in lesser numbers at Island Beach, and rarely at Clayton (has the best preservation). Again, occurrences in Zone NP9 are significantly less than those in Zone NP10. Lang and Watkins (1984) reported that at Site 540 in the Straits of Florida, the abundance of $Z$. bijugatus seemed to "parallel the fluctuating abundances of the braarudosphaerids" in the upper Eocene and lower Oligocene. This is consistent with occurrences in the current study area.

A few other species have different occurrences between upbasin and downbasin locations. Ellipsolithus macellus has a scattered occurrence in Zone NP9 in all three boreholes, but in Zone NP10 it is much more abundant at Site 605 and Island Beach than at Clayton. Sphenolithus primus and Sphenolithus anarrhopus also occur in greater numbers at Site 605 , possibly suggesting a somewhat deeper water preference. Biantholithus astralis, however, is more numerous at Clayton and Island Beach than at Site 605 and appears to prefer a more nearshore environment.

\section{Evolution of Calcareous Nannofossils}

As defined by Bramlette and Riedel (1954, p. 396), Discoaster multiradiatus usually has from 16 to 24 rays, and Discoaster barbadiensis was defined by Tan Sin Hok (1927, p. 415) as having 11 to 21 rays. Faris (1992) and Wei (1992) documented a decrease in number of rays for the species Discoaster multiradiatus in the late Paleocene and early Eocene. In the current study, D. multiradiatus also has a decreasing number of rays through time. Early forms of D. multiradiatus in the study area may have as many as 33 rays, and Wei (1992) reported specimens of $D$. multiradiatus with as many as 39 rays. There is obvious overlap in the described number of rays between $D$. multiradiatus and D. barbadiensis, and the current authors agree with Wei (1992) that the point of differentiation between these two species is artificial, and D. multiradiatus evolves into D. barbadiensis through decreasing ray number. Wei (1992) placed any specimen with less than 15 rays in $D$. barbadiensis. No systematic biometric data were collected in the current study, but an interval of question- 
Table 3. Calcareous nannofossil occurrences in Zones NP9-12 in the DSDP Site 605 borehole, Atlantic Ocean.

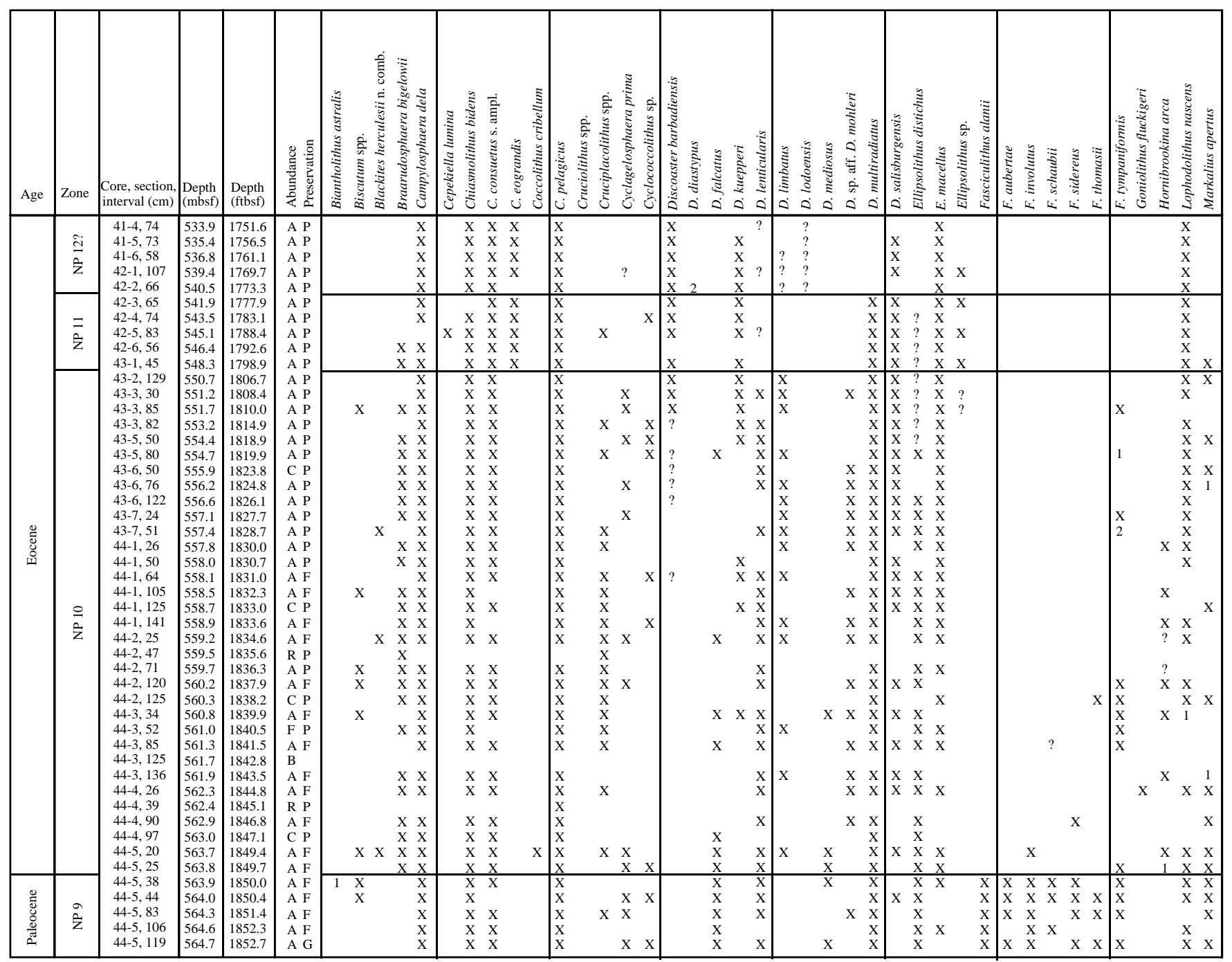

Note: See Figure 1 for location of borehole and Table 1 for symbol definitions.

able $D$. barbadiensis was recognized at Site 605 , as well as an interval that appears to contain specimens of both $D$. multiradiatus and $D$. barbadiensis (Table 3). Additional biometric studies in the future could clarify the point at which these two species can be separated and whether there is an interval that contains representatives of both species. It is unclear at this time whether the concentric features on D. multiradiatus are ever preserved on D. barbadiensis and whether the apparent smoothing of the ray perimeter on D. barbadiensis is real or caused by dissolution.

Using only the light microscope, it appears that Sphenolithus anarrhopus evolved into Sphenolithus radians in Zone NP11. Clearly identifiable specimens of $S$. anarrhopus occur in Zone NP10, and clearly identifiable specimens of $S$. radians occur in Zone NP12 at Site 605 (Table 3), but specimens from Zone NP11 are transitional and cannot be placed convincingly in either species. Studies with the SEM will be needed to document this transition more accurately.

\section{Rhomboaster vs. Tribrachiatus}

Based on an extensive SEM and light microscope study, Bybell and Self-Trail (1995) placed Rhomboaster bitrifida, Rhomboaster cuspis, and Rhomboaster calcitrapa in synonymy with Tribrachiatus bramlettei. Angori and Monechi (1996) agreed with this synonymy and stated that "spine length is probably an intraspecific variation that may be linked to preservation problems; the stratigraphical range of long-arm and short-arm specimens is in fact about the same." Wei and Zhong (1996) concurred that $R$. calcitrapa and $R$. bitrifida are the same as $R$. cuspis. They made numerous measurements and concluded that "it thus appears to be artificial to make any ray length cut-offs for different species." However, they continued to separate R. cuspis from $T$. bramlettei, even though they stated that "the FO of T. bramlettei is a difficult and imprecise datum," and "the FO of Rhomboast$e r$ is easier to apply and highly recommended in future stratigraphic correlations." The current authors remain firmly convinced that $R$. cuspis and T. bramlettei cannot be differentiated and are indeed the same species, and this is discussed in detail below.

Accepting that $T$. bramlette $i$ and $R$. cuspis are the same species, $T$. bramlette $i$, which originally was named Marthasterites bramlettei by Brönnimann and Stradner (1960) has priority over R. cuspis of Bramlette and Sullivan (1961). The genus Rhomboaster was established by Bramlette and Sullivan (1961) with R. cuspis as the type species, and the genus Tribrachiatus was established by Shamrai (1963) with Tri- 
Table 3 (continued).

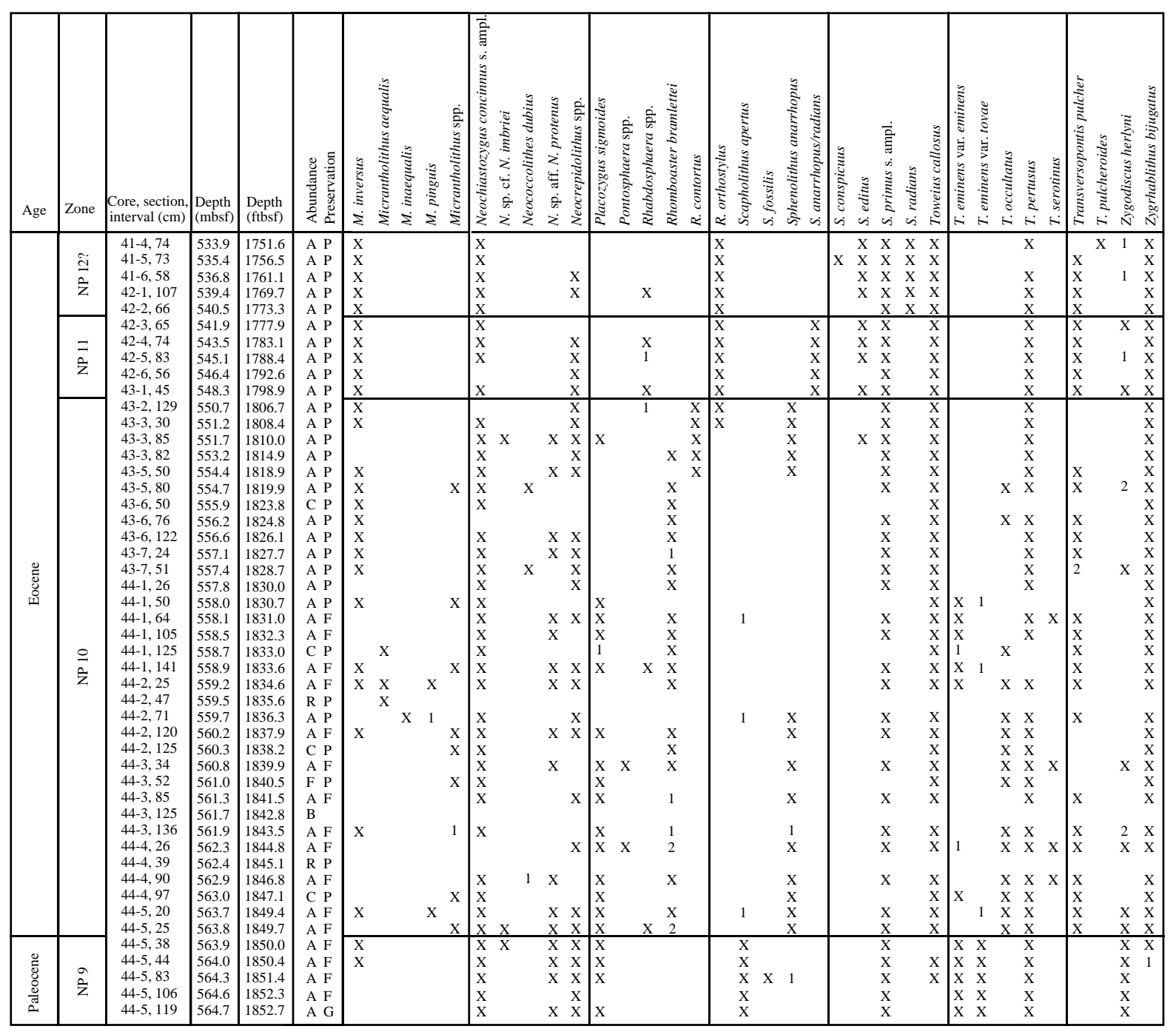

brachiatus orthostylus as the type species. By putting $R$. cuspis (the type species for the genus Rhomboaster) in synonymy with T. bramlette $i, T$. bramlettei by priority becomes the type species of the genus Rhomboaster, and T. bramlettei must be changed to Rhomboaster bramlettei, according to the International Code of Botanical Nomenclature (Greuter, 1988, 1994). Bybell and Self-Trail (1995) also transferred Tribrachiatus contortus and Tribrachiatus orthostylus to the genus Rhomboaster because of their similar construction to $R$. bramlettei, and they became Rhomboaster contortus and Rhomboaster orthostylus.

Study of Rhomboaster bramlettei specimens from Island Beach (Plate 1, Figs. 1-8), Site 605, Site 550 (provided by W. Wei), and Caravaca, Spain (provided by M.-P. Aubry) with both the light microscope and with the SEM has provided additional data concerning this species. It was confirmed that Rhomboaster cuspis is properly placed in synonymy with $R$. bramlettei because their basic construction is identical. They differ only in the length of the rays, and this appears to be due to variation within the species and preservational differences. Poorly preserved samples contain primarily short-rayed forms, and better preserved samples contain primarily long-rayed forms. However, as can been seen in Plate 1, Figures 3, 6-8, there can be a significant amount of variation within a single sample, with a corresponding variation in ray length.
In the lowest part of Zone NP10, calcareous nannofossil preservation frequently is somewhat poorer than farther up in the zone, and this may well be related to the dissolution interval that frequently occurs near the Zone NP9/NP10 boundary. Early specimens of $R$. bramlette $i$ in the study area typically have short rays, which is attributed to dissolution, while later forms frequently have longer rays.

In order to approximate the settling of specimens on a glass slide, clay models of long-rayed and short-rayed forms of $R$. bramlettei were dropped 6 in onto a flat surface. Long-rayed forms consistently landed in a position corresponding to Figure 6A (T. bramlettei on fig. $2 \mathrm{a}$ of Aubry, 1996), while short-rayed forms consistently landed in a position closely corresponding to Figure 6B (R. cuspis on fig. 2c of Aubry, 1996). The longer rays acted as struts that supported the specimen in a different position from the shorter rayed model.

As mentioned above, Wei and Zhong (1996) continued to distinguish both $R$. cuspis and T. bramlettei, although they stated that "differentiation of these taxa is difficult or not possible when they cooccur, particularly when overgrowth is severe." Romein (1979) and Aubry (1996) also distinguished between R. cuspis and T. bramlettei (T. nunnii in Romein) on the basis of apparent structural differences. Aubry (1996, fig. 2a) described Tribrachiatus bramlettei as "showing the arrangement of the two superposed triplets," while with $R$. cuspis (Aubry, 1996, fig. 2c) "the upper and lower tips of the triplets 
Table 3 (continued).

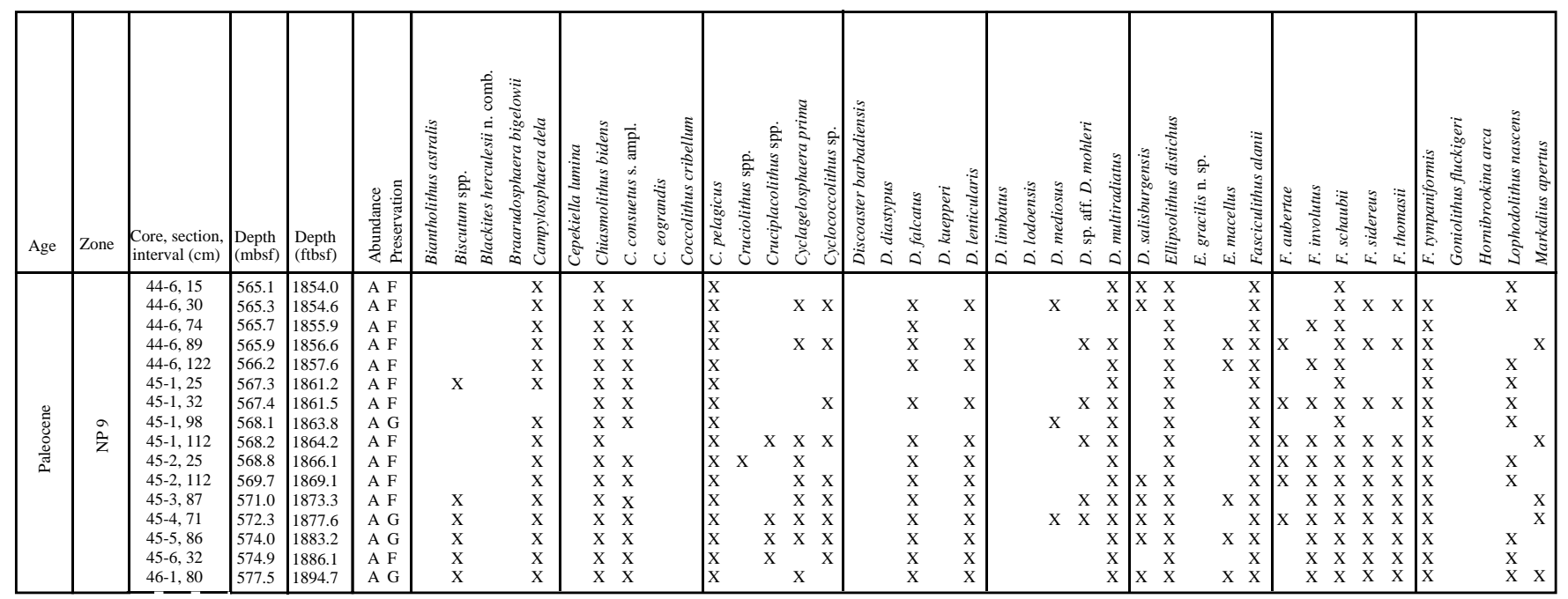

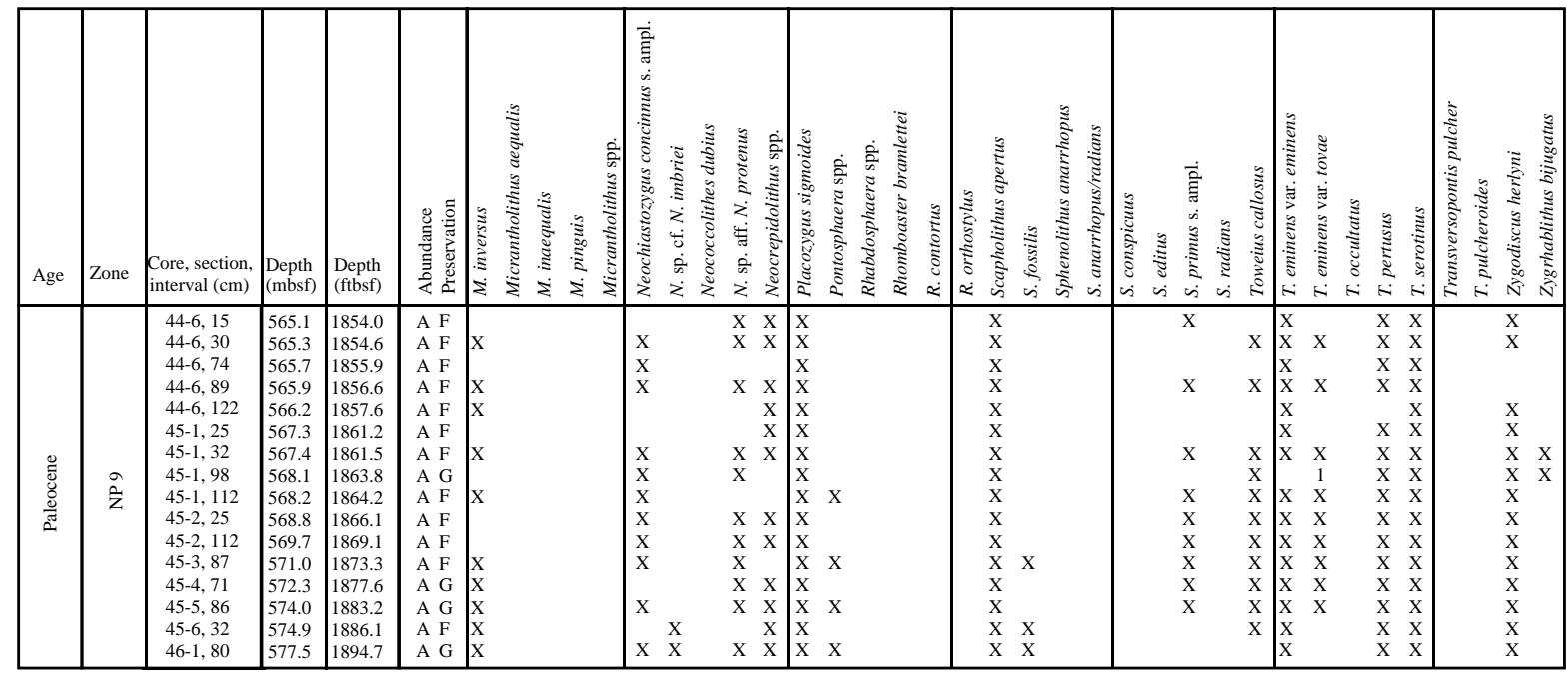

are on a line that is oblique and inverse to the plane of symmetry of the rhombohedron." The current authors disagree with these structural differences as a viable way to separate $R$. cuspis from $T$. bramlettei because they only represent two different views of the same species. Figure 6 illustrates a clay model from two different views: view A corresponds to Aubry's (1996) figure 2a, which she would call $T$. bramlettei, and view B (same specimen tilted forward $30^{\circ}$ ) corresponds to Aubry's figure 2c, which she would call R. cuspis. Rhomboaster cuspis and T. bramlettei have exactly the same structure and are properly placed in one species, $R$. bramlettei.

The current authors propose that the clay model representation of T. bramlettei on figure 5-1e, 2e, 3e of Wei and Zhong (1996), which has all six ray terminations in the same plane, does not correspond to any known fossil specimens, and even their scanning electron photomicrographs of T. bramlettei on figure 4, specimens 3-4,6 clearly show that the ray terminations are not in the same plane. There is no doubt that longer rayed forms do appear to be flatter than shorter rayed forms. However, as stated by Bybell and Self-Trail (1995), "a clay model of $R$. cuspis with very short arms was turned into a model of $R$. bramlettei merely by lengthening the rays. As the rays were lengthened, in order to maintain symmetry within a specimen, the an- gles on each face of the rhombohedron were forced to change: the angle increased on the corner without a ray" (the $\beta$ angle of Wei and Zhong, 1996), "and the angles decreased on the three corners containing rays." However, Wei and Zhong used the $\beta$ angle to differentiate Rhomboaster cuspis from Tribrachiatus bramlettei, and they stated that "specimens with angle $\beta<130^{\circ}$ look convex and thick and were recorded as Rhomboaster; those with angle $\beta>130^{\circ}$ appear relatively flat and were recorded as T. bramlettei." But their long-rayed specimen on figure $5-1 \mathrm{~d}, 2 \mathrm{~d}, 3 \mathrm{~d}$, which they placed in $R$. cuspis, has a $\beta$ angle of more than $130^{\circ}$. The current authors believe that use of the $\beta$ angle is a misleading and inaccurate measurement because the size of the angle can appear to vary significantly just by viewing the specimen from slightly different positions and with different ray lengths. The simplest and easiest solution is not to separate R. cuspis and $T$. bramlettei.

The Clayton borehole contained only the lower part of Zone NP10, but Island Beach, Site 605, Site 550, and Caravaca also contain material from the upper part of Zone NP10. Extensive examination of both lower and upper Zone NP10 material confirmed that $R$. bramlettei does not change its basic shape within Zone NP10 by flattening. Specimens from Plate 1, Figures 3, 6-8 are all from the upper 


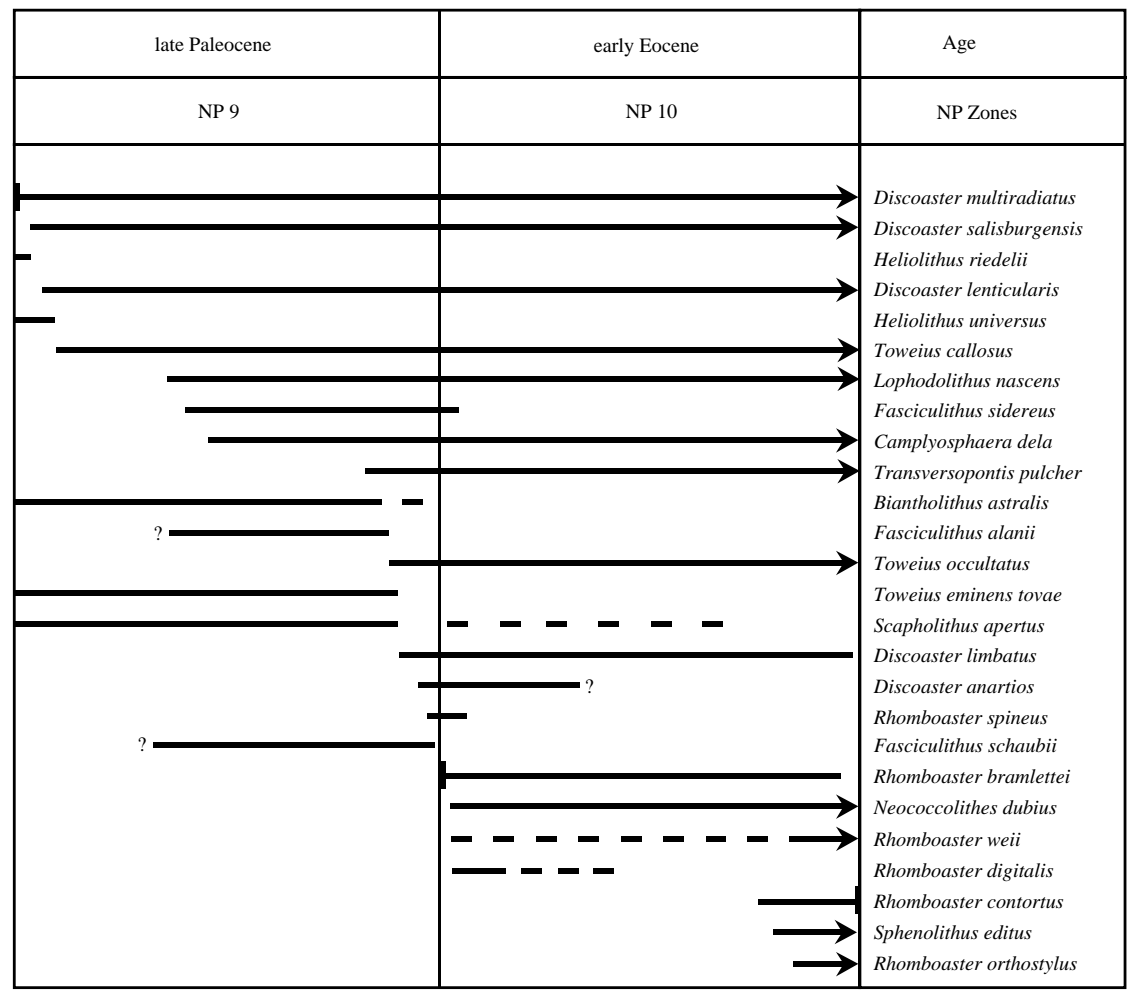

Figure 2. Stratigraphically useful calcareous nannofossil species in Zones NP9 and NP10 in New Jersey and the offshore Atlantic Ocean. A question mark indicates an unknown termination for a species' range, a dashed horizontal line indicates sporadic occurrence, and an arrow indicates that the range extends into Zone NP11. A horizontal line with a vertical end bar represents the occurrence of Martini's (1971) zonal marker species. (Author correction: Toweius eminens tovae should be Toweius eminens var. tovae.)

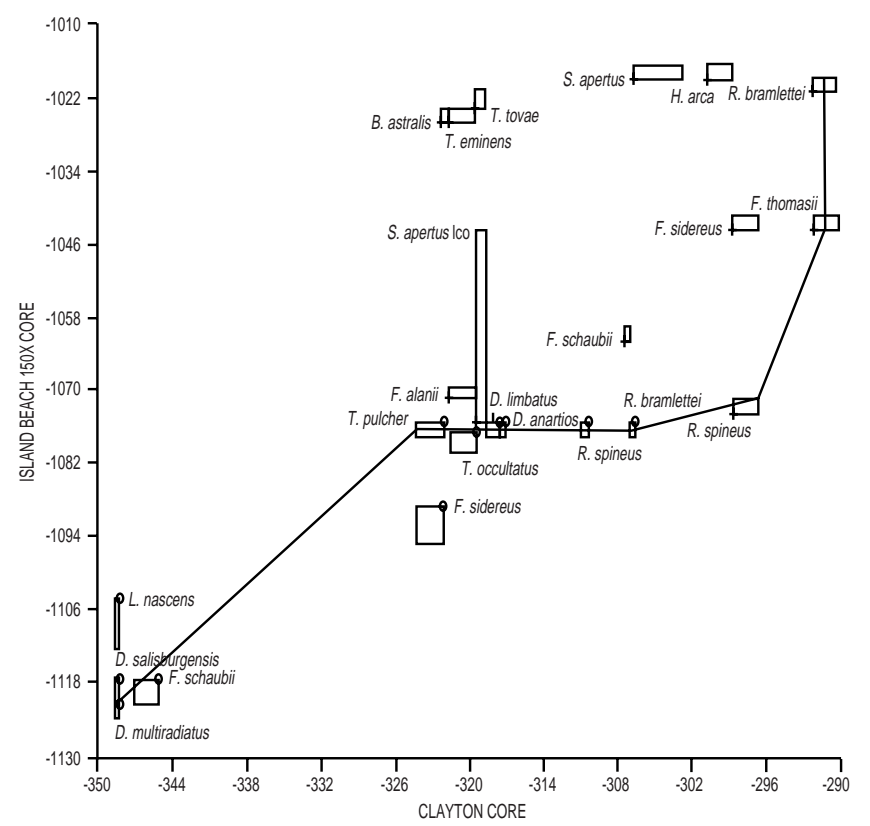

Figure 3. Graphic correlation plot of the Island Beach 150X borehole and the Clayton borehole, New Jersey. For Figures 3, 4, and 5, stratigraphic up is to the top and to the right. First occurrence events are plotted as "o" with the sample-interval boxes extended down and to the left; last occurrence events are plotted as "+" with the sample-interval boxes extended up and to the right.

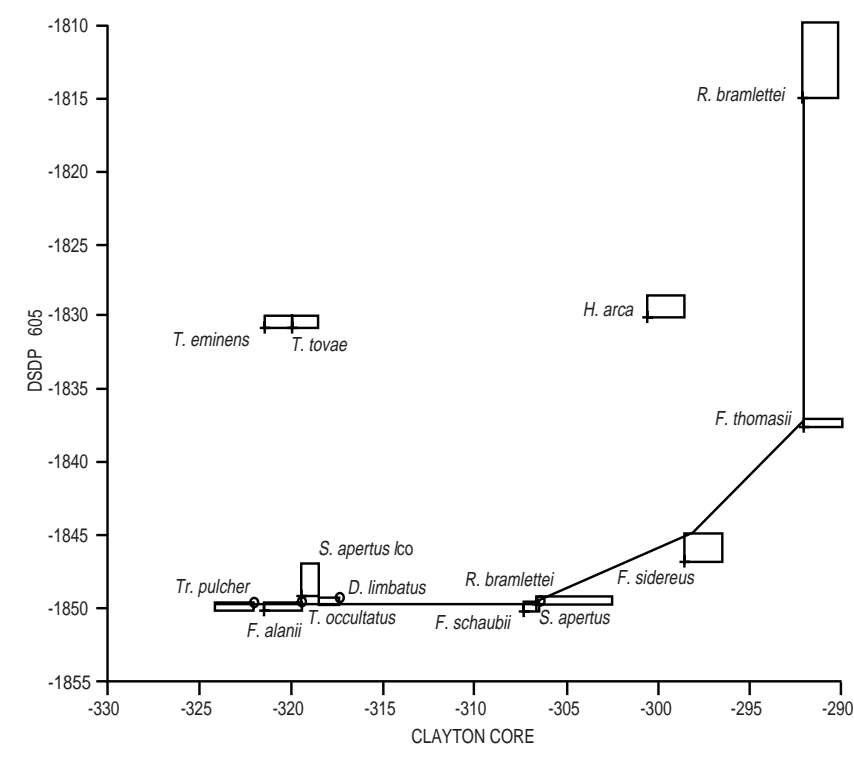

Figure 4. Graphic correlation plot of the Clayton borehole, New Jersey, and the DSDP Site 605 borehole, Atlantic Ocean. See Figure 3 caption for explanation of symbols. 


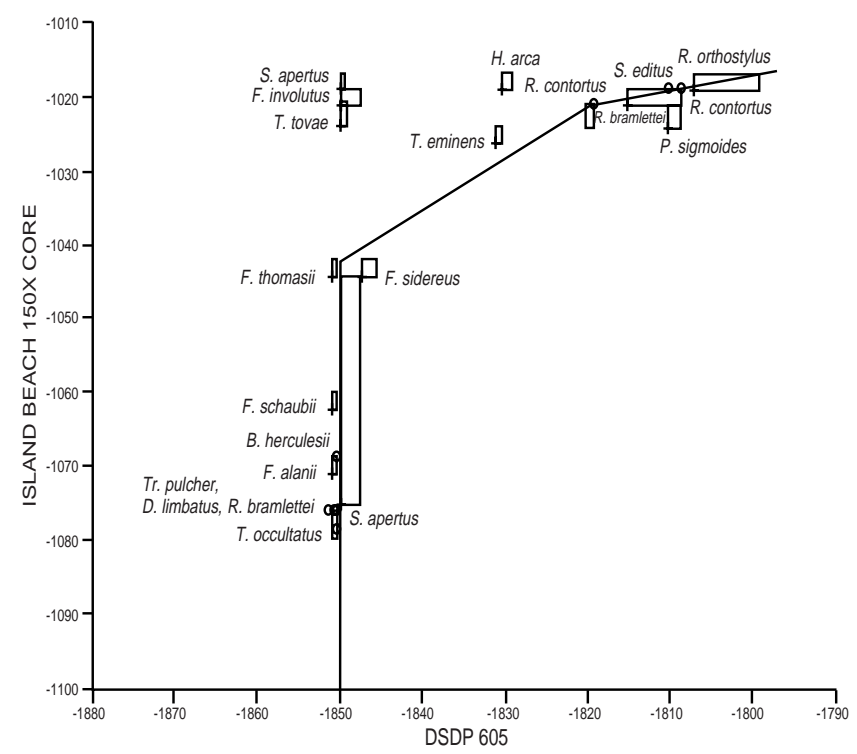

Figure 5. Graphic correlation plot of the Island Beach 150X borehole, New Jersey, and the DSDP Site 605 borehole, Atlantic Ocean. See Figure 3 for explanation of symbols.

part of Zone NP10, and they are indistinguishable from lower Zone NP10 specimens that were illustrated by Bybell and Self-Trail (1995) on plates 22 and 23.

\section{SYSTEMATIC PALEONTOLOGY}

\section{Genus BLACKITES}

Blackites herculesii (Stradner, 1969) Bybell \& Self-Trail, n. comb.

$$
\text { (P1. 5, Figs. 3-6) }
$$

Rhabdosphaera herculea Stradner, 1969, p. 415, pl. 89, figs. 9-12.

Remarks: The SEM photomicrograph on Plate 5, Figure 4 clearly shows the presence of three cycles on the basal plate, which conforms to the description of the genus Blackites as emended by Stradner in Stradner and Edwards (1968). Stradner (1969, p. 415) stated that the derivation of the name was "Hercules = name of hero (Greek Mythology)." Therefore, herculea has been changed to herculesii according to the rules of the International Code of Botanical Nomenclature (Greuter, 1988, 1994, Recommendation 23A), which was discussed in van Heck (1990, p. 20).

Occurrence: Blackites herculesii only occurs in the early Eocene Zone NP10 in the Island Beach borehole, New Jersey and in the DSDP Site 605 borehole.

\section{Genus ELLIPSOLITHUS}

\section{Ellipsolithus sp.}

(Pl. 4, Figs. 3-5)

Remarks: Ellipsolithus sp., which contains numerous small perforations in the central area, also has been observed by Aubry (pers. comm., 1996), who will publish a description of this species. In the light microscope, it can be difficult to distinguish between Ellipsolithus sp. and Ellipsolithus distichus in poorly preserved material, particularly if there is extensive recrystallization, which fills in most or all of the perforations in E. distichus. However, Ellipsolithus $\mathrm{sp}$. has at least one additional ring of perforations in the central area and frequently has a wider central region than $E$. distichus.

Occurrence: Ellipsolithus sp. was observed in Zone NP10 in the Island Beach borehole and probably in Zones NP10-12 in the DSDP Site 605 borehole where poor preservation made recognition of this species difficult.

\section{Genus RHOMBOASTER}

Rhomboaster digitalis (Aubry, 1996) Bybell \& Self-Trail n. comb. (Pl. 2, Figs. 3-7)

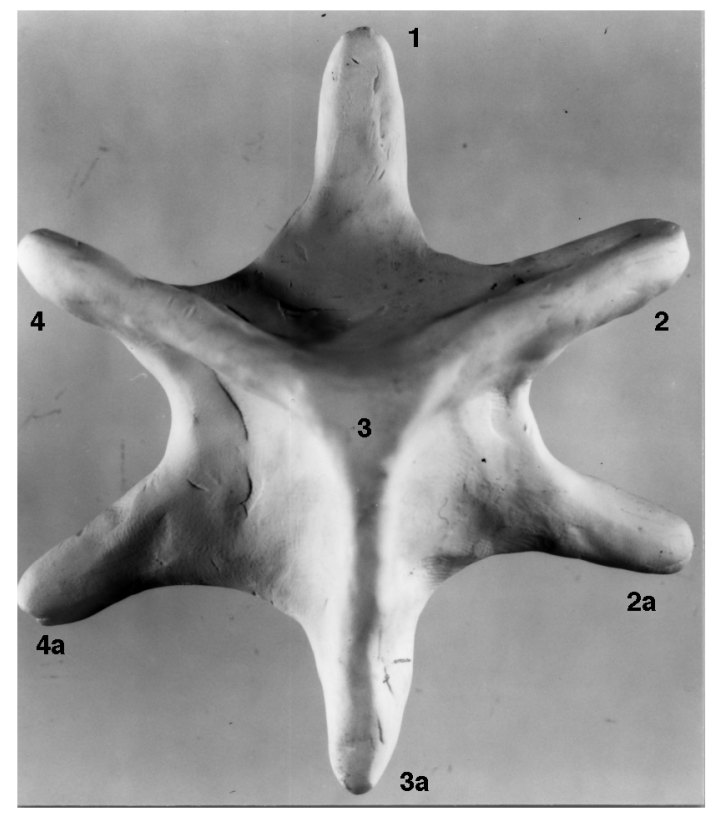

A

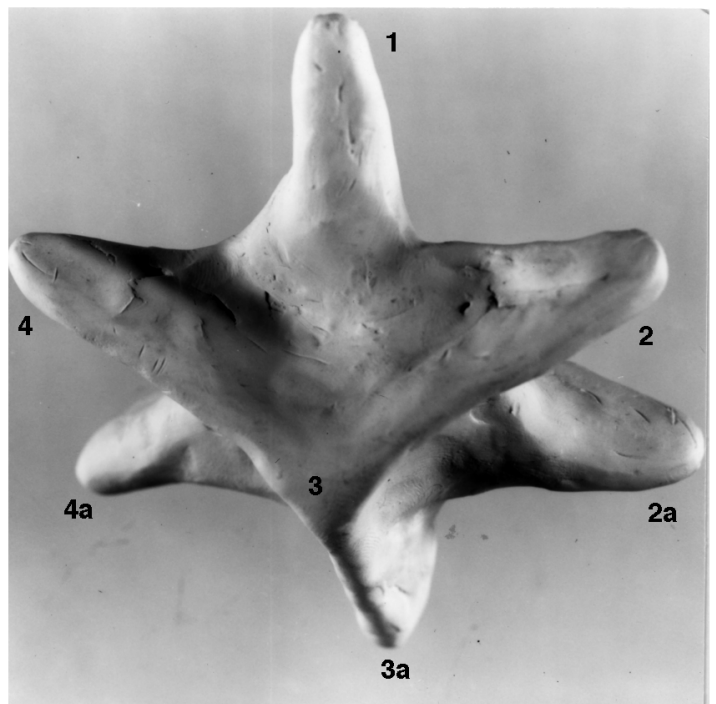

B

Figure 6. Clay model of Rhomboaster bramlettei, showing two different views of same specimen. View A corresponds to Tribrachiatus bramlettei of Aubry (1996, fig. 2-a), which she reproduced from Romein (1979, p. 193), and view B corresponds to Rhomboaster cuspis of Aubry (1996, fig. 2-c), which she reproduced from Romein $(1979$, p. 190). Numbers on the figure correspond to those in Aubry (1996) and Romein (1979).

Tribrachiatus digitalis Aubry, 1996, p. 245, pl. 1, figs. 1-12; pl. 2, figs. 11-12

Remarks: The original illustrations of this species were confined to light micrographs. Scanning electron micrographs now are provided for this species (Plate 2, figs. 3-7). Tribrachiatus digitalis is herein changed to Rhomboaster digitalis because its structure is similar to other members of this genus. This combination was suggested but not officially proposed by Angori and Monechi (1996). In heavily overgrown specimens it can be difficult to distinguish the flat ray terminations of $R$. digitalis from the offset terminations of Rhomboaster contortus.

It is possible that Rhomboaster digitalis evolved into $R$. contortus, which it most closely resembles and predates, by torquing of each ray. However, the 
ranges of $R$. digitalis and $R$. contortus do not appear to overlap, and no intermediary specimens have been observed. Wei and Zhong (1996) proposed that $R$. bramlettei evolved into $R$. contortus by flattening and shifting of the rays. Both scenarios cannot be correct, and additional studies of closely spaced samples are necessary to resolve this issue.

Occurrence: Rhomboaster digitalis occurs in the lower part of Zone NP10 in the Island Beach borehole (Table 2). Aubry (1996) reported it from DSDP Sites 117 and 550, the Owaina-Gurnah section in Egypt, and the Island Beach borehole. This short-ranging species is absent at Clayton and Site 605, and this may be due to a small unconformity encompassing this part of the section.

\section{Rhomboaster weii Bybell \& Self-Trail n. sp.}

$$
\text { (Pl. 3, Figs. 5-9) }
$$

Diagnosis: A robust member of the genus Rhomboaster with triradiate arms that terminate bluntly at an equal distance from the central area. This species is named in honor of Wuchang Wei.

Description: A triradiate calcareous nannofossil consisting of three thick and somewhat rectangular rays that are bluntly truncated and with no conspicuous terminal notch or bifurcation. The angle between each ray is equal, resulting in $R$. weii having a highly symmetrical appearance. Specimens of $R$. weii exhibit a slight thickening of the central area which becomes more pronounced in specimens that are somewhat overgrown. The diameter of $R$. weii ranges from 5 to $8 \mu \mathrm{m}$.

Remarks: Rhomboaster weii most closely resembles Rhomboaster orthostylus, which also has three rays. However, $R$. weii can be differentiated from $R$. orthostylus by its thicker and more truncated rays, its lack of terminal bifurcation, and its broad, thickened central area. Rhomboaster weii typically is somewhat smaller than $R$. orthostylus and has its first appearance datum in lower Zone NP10, well before the first appearance of $R$. contortus or $R$. orthostylus. Rhomboaster weii is easily identified from scanning electron photomicrographs, but it is more difficult to distinguish from heavily overgrown specimens of $R$. orthostylus in the light microscope. It is unclear where $R$. weii fits in the genus Rhomboaster lineage.

Holotype: Plate 3, Figure 5, SEM photomicrograph number 510-6.

Paratype: Plate 3, Figure 6, SEM photomicrograph number 530-5.

Type Locality: Holotype, New Jersey, Island Beach borehole 150X, $1016.9 \mathrm{ft}$, Zone NP11, Manasquan Formation. Paratype, New Jersey, Island Beach borehole 150X, $1073.9 \mathrm{ft}$, Zone NP10, Manasquan Formation.

Occurrence: This species occurs in lower Zone NP10 and lower Zone NP11 in New Jersey and in Alabama. Rhomboaster weii is never very common, and it is quite possible that its range extends beyond what is recorded here.

Depository: The original scanning electron photomicrographs and negatives are stored at the U.S. Geological Survey in Reston, VA.

\section{SUMMARY}

Examination of closely spaced samples from all three sites made it possible to document significant differences in the ages of preserved sediments from borehole to borehole and to document changes in floral abundances from an upbasin/downbasin perspective. These differences, combined with biostratigraphic information from other boreholes in the New Jersey coastal plain, reveal a complex mosaic of sediments in this region. For example, in the Clayton borehole, the lower part of Zone NP9 is missing, whereas it is present at Island Beach. The Clayton borehole contains the uppermost part of Zone NP9, but sediments of this age are missing at both Island Beach and Site 605. The lowest part of Zone NP10 appears to be present at all three locations. The upper part of Zone NP10 is missing in the Clayton borehole but is present at Island Beach and the Site 605 borehole.

There is evidence that the distribution of Hornibrookina arca and Toweius eminens var. eminens may be controlled by paleoenvironmental conditions, although the nature of these conditions is unknown. In the Clayton borehole, the most updip (upbasin) of the three, T. eminens var. eminens has its last appearance at an earlier date than the two downdip (downbasin) boreholes, possibly indicating a deeper water preference for this species.
In the study area, braarudosphaerids have higher abundances in deeper water than in shallower water, and significantly higher abundances in Zone NP10 than in Zone NP9. Neither preservation nor water depth appear to be controlling factors. This unexpected distribution offers only additional puzzlement to the already confusing distribution of this group. The distribution of Zygrhablithus bijugatus parallels that of the braarudosphaerids.

Discoaster multiradiatus appears to evolve into Discoaster barbadiensis, and Sphenolithus anarrhopus appears to evolve into Sphenolithus radians.

Through examination of many specimens, it is confirmed that Rhomboaster cuspis is indeed a junior synonym of Tribrachiatus bramlettei, and the proper name is Rhomboaster bramlettei. Tribrachiatus digitalis is changed to Rhomboaster digitalis, the new species Rhomboaster weii is established, and Rhabdosphaera herculea is changed to Blackites herculesii.

\section{ACKNOWLEDGMENTS}

We wish to thank James J. Pospichal of Hamilton College and Timothy J. Bralower of the University of North Carolina for their thoughtful reviews of this paper. We wish to dedicate this paper to James P. Owens, who spent many years studying the geology of New Jersey. For his many insights and undaunted enthusiasm, we are forever indebted to him. This paper was written as part of the International Geological Correlation Programme (IGCP) Project 308.

\section{REFERENCES}

Angori, E., and Monechi, S., 1996. High-resolution calcareous nannofossil biostratigraphy across the Paleocene/Eocene boundary at Caravaca (southern Spain). Israel J. Earth Sci., 44:197-206.

Applegate, J.L., and Wise, S.W., Jr., 1987. Eocene calcareous nannofossils, Deep Sea Drilling Project Site 605, upper continental rise off New Jersey U.S.A. In van Hinte, J.E., Wise, S.W., Jr., et al., Init. Repts. DSDP, 93: Washington (U.S. Govt. Printing Office), 685-698.

Aubry, M.-P., 1996. Towards an upper Paleocene-lower Eocene high resolution stratigraphy based on calcareous nannofossil stratigraphy. Israel J. Earth Sci., 44:239-253.

Aubry, M.-P., Berggren, W.A., Stott, L., and Sinha, A., 1996. The upper Paleocene-lower Eocene stratigraphic record and the Paleocene/Eocene boundary carbon isotope excursion: implications for geochronology. In Knox, R.W.O'B, Corfield, R.M., and Dunay, R.E. (Eds.), Correlation of the Early Paleogene in Northwestern Europe, Spec. Publ.-Geo. Soc. Am., 101:353-380.

Berggren, W.A., and Aubry, M.-P., 1996. A late Paleocene-early Eocene NW European and North Sea magnetobiochronological correlation network. In Knox, R.W.O'B, Corfield, R.M., and Dunay, R.E. (Eds.), Correlation of the Early Paleogene in Northwest Europe, Spec. Publ.-Geo. Soc. Am., 101:309-352.

Berggren, W.A., Kent, D.V., Flynn, J.J., and van Couvering, J.A., 1985. Cenozoic geochronology. Geol. Soc. Am. Bull., 96:1407-1418.

Bralower, T.J., and Mutterlose, J., 1995. Calcareous nannofossil biostratigraphy of Site 865, Allison Guyot, Central Pacific Ocean: a tropical Paleogene reference section. In Winterer, E.L., Sager, W.W., Firth, J.V., and Sinton, J.M. (Eds.), Proc. ODP, Sci. Results, 143: College Station, TX (Ocean Drilling Program), 31-74.

Bramlette, M.N., and Riedel, W.R., 1954. Stratigraphic value of discoasters and some other microfossils related to Recent coccolithophores. J. Paleontol., 28:385-403.

Bramlette, M.N., and Sullivan, F.R., 1961. Coccolithophorids and related nannoplankton of the early Tertiary in California. Micropaleontology, 7:129-188

Brönnimann, P., and Stradner, H., 1960. Die Foraminiferen- und Discoasteridenzonen von Kuba und ihre interkontinentale Korrelation. Erdoel-Zeit., 76:364-369.

Bukry, D., 1971. Cenozoic calcareous nannofossils from the Pacific Ocean. Trans. San Diego Soc. Nat. Hist., 16:303-327. 
1973. Low-latitude coccolith biostratigraphic zonation. In Edgar, N.T., Saunders, J.B., et al., Init. Repts. DSDP, 15: Washington (U.S. Govt. Printing Office), 685-703.

1978. Biostratigraphy of Cenozoic marine sediment by calcareous nannofossils. Micropaleontology, 24:44-60.

Bybell, L.M., and Gartner, S., 1972. Provincialism among mid-Eocene calcareous nannofossils. Micropaleontology, 18:319-336.

Bybell, L.M., and Self-Trail, J.M., 1995. Evolutionary, biostratigraphic, and taxonomic study of calcareous nannofossils from a continuous Paleocene/Eocene boundary section in New Jersey. Geol. Surv. Prof. Pap. U.S., 1554.

Faris, M., 1992. Morphometry of Discoaster multiradiatus Bramlette \& Riedel (1954) and its biochronological significance in the early Paleogene of Egypt. Delta J. Sci., 16:152-170.

Gibson, T.G., and Bybell, L.M., 1995. Sedimentary patterns across the Paleocene/Eocene boundary in the Atlantic and Gulf Coastal Plains of the United States. Geologie, 103:237-265.

Gibson, T.G., Bybell, L.M., and Owens, J.P., 1993. Latest Paleocene lithologic and biotic events in neritic deposits of southwestern New Jersey. Paleoceanography, 8:495-514.

Greuter, W., 1988. International Code of Botanical Nomenclature. Königstein (Koeltz Scientific Books), 1-328.

, 1994. International Code of Botanical Nomenclature. Königstein (Koeltz Scientific Books), 1-389.

Hood, K.C., 1996. Evaluating the use of average composite sections and derived correlations in the graphic correlation technique. In Mann, K.O., and Lane, H.R., (Eds.), Graphic Correlation: Spec. Publ.-Soc. Econ. Petrol. Mineral., 53:83-93.

Jiang, Y.W., and Wise, S.W., 1987. Paleocene-Eocene calcareous nannofossils of onshore wells from the coastal plain of New Jersey and Maryland, U.S.A. In van Hinte, J.E., Wise, S.W., Jr., et al., Init. Repts. DSDP, 93: Washington (U.S. Govt. Printing Office), 699-711.

Lang, T.H., and Wise, S.W., Jr., 1987. Neogene and Paleocene-Maestrichtian calcareous nannofossil stratigraphy, Deep Sea Drilling Project Sites 604 and 605, Upper Continental Rise off New Jersey: sedimentation rates, hiatuses, and correlations with seismic stratigraphy. In van Hinte, J.E., Wise, S.W., Jr., et al., Init. Repts. DSDP, 93: Washington (U.S. Govt. Printing Office), 661-683.

Martini, E., 1971. Standard Tertiary and Quaternary calcareous nannoplankton zonation. In Farinacci, A. (Ed.), Proc. 2nd Int. Conf. Planktonic Microfossils Roma: Rome (Ed. Tecnosci.), 2:739-785.

Miller, K.G., Sugarman, P., Van Fossen, M., Liu, C., Browning, J.V., Queen, D., Aubry, M.-P., Burckle, L.D., Goss, M., and Bukry, D., 1994. Island Beach site report. In Miller, K.G., et al., Proc. ODP, Init. Repts., 150X: College Station, TX (Ocean Drilling Program), 5-33.

Okada, H., and Bukry, D., 1980. Supplementary modification and introduction of code numbers to the low-latitude coccolith biostratigraphic zonation (Bukry, 1973; 1975). Mar. Micropaleontol., 5:321-325.
Olsson, R.K., and Wise, S.W., 1987. Upper Maestrichtian to middle Eocene stratigraphy of the New Jersey slope and coastal plain. In van Hinte, J.E., Wise, S.W., Jr., et al., Init. Repts. DSDP, 93 (Pt. 2): Washington (U.S. Govt. Printing Office), 1343-1365.

Perch-Nielsen, K., 1985. Cenozoic calcareous nannofossils. In Bolli, H.M., Saunders, J.B., and Perch-Nielsen, K. (Eds.), Plankton Stratigraphy: Cambridge (Cambridge Univ. Press), 427-554.

Pospichal, J.J., and Wise, S.W., Jr., 1990. Paleocene to middle Eocene calcareous nannofossils of ODP Sites 689 and 690, Maud Rise, Weddell Sea. In Barker, P.F., Kennett, J.P., et al., Proc. ODP. Sci. Results, 113: College Station, TX (Ocean Drilling Program), 613-638.

Romein, A.J.T., 1979. Lineages in early Paleogene calcareous nannoplankton. Utrecht Micropaleontol. Bull., 22:1-231.

Shamrai, I.A., 1963. Nekotorye formy verkhnemelovykh i paleogenovykh kokkolitov i diskoasterov na yuge russkoi platformy. Izv. Vyssh. Ucheb. Zaved. Geol. i Razy., 6:27-40.

Siesser, W.G., Bralower, T.J., and De Carlo, E.H., 1992. Mid-Tertiary Braarudosphaera-rich sediments on the Exmouth Plateau. In von Rad, U., Haq, B.U., et al., Proc. ODP, Sci. Results, 122: College Station, TX (Ocean Drilling Program), 653-663.

Stradner, H., 1969. The nannofossils of the Eocene flysch in the Hagenbach Valley (northern Vienna Woods), Austria. Annal. Soc. Geol. Pologne, 39:403-432.

Stradner, H., and Edwards, A.R., 1968. Electron microscopic studies on upper Eocene coccoliths from the Oamaru diatomite, New Zealand. Jahrb. Geol. Bundesanst. (Austria), 13:1-66.

Tan Sin Hok, 1927. Discoasteridae incertae sedis. Koninkl. Nederlandse Akad. Wetenschap. Proc. Sect. Sci., 30:411-419.

Thomas, E., 1996. The Paleocene-Eocene benthic foraminiferal extinction and stable isotope anomalies. In Knox, R.W. O'B, Corfield, R.M., and Dunary, R.E. (Eds.), Correlation of the Early Paleogene in Northwest Europe, Spec. Publ.-Geol. Soc. Am., 101:401-441.

van Heck, S.E., 1990. The ICBN: things you need to know: 1. Int. Nannoplankton Assoc. Newslet., 12:19-20.

van Hinte, J., Wise, S.W., and Leg 93 Shipboard Party. 1987. Sites 604 and 605. In van Hinte, J.E., Wise, S.W., Jr., et al., Init. Repts. DSDP, 93: Washington (U.S. Govt. Printing Office), 277-413.

Wei, W., 1992. Biometric study of Discoaster multiradiatus and its biochronological utility. Mem. Sci. Geol., 32:219-235.

Wei, W., and Zhong, S., 1996. Taxonomy and magnetobiochronology of Tribrachiatus and Rhomboaster, two genera of calcareous nannofossils. J. Paleontol., 70:7-22.

Date of initial receipt: 18 March 1996

Date of acceptance: 16 September 1996

Ms 150XSR-307 


\section{APPENDIX}

Calcareous Nannofossil Species Considered in this Report

(In alphabetical order of generic epithets)

Biantholithus astralis Steinmetz \& Stradner, 1984

Biantholithus sparsus Bramlette \& Martini, 1964

Blackites herculesii (Stradner, 1969) Bybell \& Self-Trail n. comb.

Braarudosphaera bigelowii (Gran \& Braarud, 1935) Deflandre, 1947

Campylosphaera dela (Bramlette \& Sullivan, 1961) Hay \& Mohler, 1967

Cepekiella lumina (Sullivan, 1965) Bybell, 1975

Chiasmolithus bidens (Bramlette \& Sullivan, 1961) Hay \& Mohler, 1967

Chiasmolithus consuetus (Bramlette \& Sullivan, 1961) Hay \& Mohler, 1967

Chiasmolithus eograndis Perch-Nielsen, 1971

Coccolithus cribellum (Bramlette \& Sullivan, 1961) Stradner, 1962

Coccolithus pelagicus (Wallich, 1877) Schiller, 1930

Cruciplacolithus tenuis (Stradner, 1961) Hay \& Mohler in Hay et al., 1967

Cyclagelosphaera prima (Bukry, 1969) Bybell \& Self-Trail, 1995

Discoaster anartios Bybell \& Self-Trail, 1995

Discoaster araneus Bukry, 1971

Discoaster barbadiensis Tan Sin Hok, 1927

Discoaster binodosus Martini, 1958

Discoaster diastypus Bramlette \& Sullivan, 1961

Discoaster falcatus Bramlette \& Sullivan, 1961

Discoaster kuepperi Stradner, 1959

Discoaster lenticularis Bramlette \& Sullivan, 1961

Discoaster limbatus Bramlette \& Sullivan, 1961

Discoaster lodoensis Bramlette \& Riedel, 1954

Discoaster mediosus Bramlette \& Sullivan, 1961

Discoaster mohleri Bukry \& Percival, 1971

Discoaster multiradiatus Bramlette \& Riedel, 1954

Discoaster salisburgensis Stradner, 1961

Discoaster splendidus Martini, 1960

Ellipsolithus distichus (Bramlette \& Sullivan, 1961) Sullivan, 1964

Ellipsolithus macellus (Bramlette \& Sullivan, 1961) Sullivan, 1964

Ericsonia fenestrata (Deflandre \& Fert, 1954) Stradner in Stradner and Edwards, 1968

Ericsonia subpertusa Hay \& Mohler, 1967

Fasciculithus alanii Perch-Nielsen, 1971

Fasciculithus aubertae Haq \& Aubry, 1981

Fasciculithus involutus Bramlette \& Sullivan, 1961

Fasciculithus schaubii Hay \& Mohler, 1967

Fasciculithus sidereus Bybell \& Self-Trail, 1995

Fasciculithus thomasii Perch-Nielsen, 1971
Fasciculithus tympaniformis Hay \& Mohler in Hay et al., 1967

Goniolithus fluckigeri Deflandre, 1957

Heliolithus riedelii Bramlette \& Sullivan, 1961

Heliolithus universus Wind \& Wise, 1976

Holodiscolithus macroporus (Deflandre in Deflandre and Fert, 1954) Roth, 1970

Holodiscolithus solidus (Deflandre in Deflandre and Fert, 1954) Roth, 1970

Hornibrookina arca Bybell \& Self-Trail, 1995

Lophodolithus nascens Bramlette \& Sullivan, 1961

Markalius apertus Perch-Nielsen, 1979

Markalius inversus Bramlette \& Martini, 1964

Micrantholithus aequalis Sullivan, 1964

Micrantholithus inaequalis Martini, 1961

Micrantholithus pinguis Bramlette \& Sullivan, 1961

Neochiastozygus concinnus (Martini, 1961) Perch-Nielsen, 1971

Neochiastozygus imbriei Haq \& Lohmann, 1975

Neococcolithes dubius (Deflandre in Deflandre and Fert, 1954) Black, 1967

Neococcolithes protenus (Bramlette \& Sullivan, 1961) Black, 1967

Placozygus sigmoides (Bramlette \& Sullivan, 1961) Romein, 1979

Rhomboaster bramlettei (Brönnimann \& Stradner, 1960) Bybell \& SelfTrail, 1995

Rhomboaster contortus (Stradner, 1958) Bybell \& Self-Trail, 1995

Rhomboaster digitalis (Aubry,1996) Bybell \& Self-Trail n. comb.

Rhomboaster orthostylus (Shamrai, 1963) Bybell \& Self-Trail, 1995

Rhomboaster spineus (Shafik \& Stradner, 1971) Perch-Nielsen, 1984

Rhomboaster weii Bybell \& Self-Trail n. sp.

Scapholithus apertus Hay \& Mohler, 1967

Scapholithus fossilis Deflandre in Deflandre and Fert, 1954

Sphenolithus anarrhopus Bukry \& Bramlette, 1969

Sphenolithus conspicuus Martini, 1976

Sphenolithus editus Perch-Nielsen, 1978

Sphenolithus primus Perch-Nielsen, 1971

Sphenolithus radians Deflandre in Grasse, 1952

Toweius callosus Perch-Nielsen, 1971

Toweius eminens var. eminens (Bramlette \& Sullivan, 1961) Gartner, 1971

Toweius eminens var. tovae Bybell \& Self-Trail, 1995

Toweius occultatus (Locker, 1967) Perch-Nielsen, 1971

Toweius pertusus (Sullivan, 1965) Romein, 1979

Toweius serotinus Bybell \& Self-Trail, 1995

Transversopontis pulcher (Deflandre in Deflandre and Fert, 1954) PerchNielsen, 1967

Transversopontis pulcheroides (Sullivan, 1964) Baldi-Beke, 1971

Zygodiscus herlyni Sullivan, 1964

Zygrhablithus bijugatus (Deflandre in Deflandre and Fert, 1954) Deflandre, 1959 


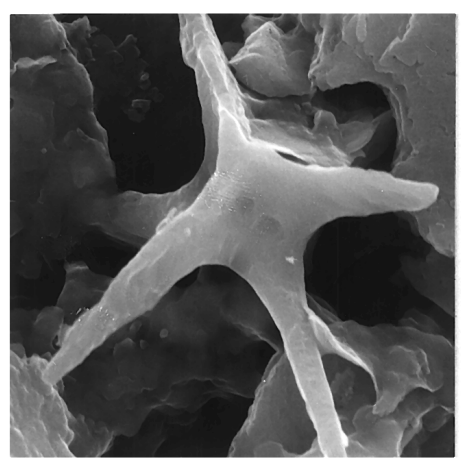

1

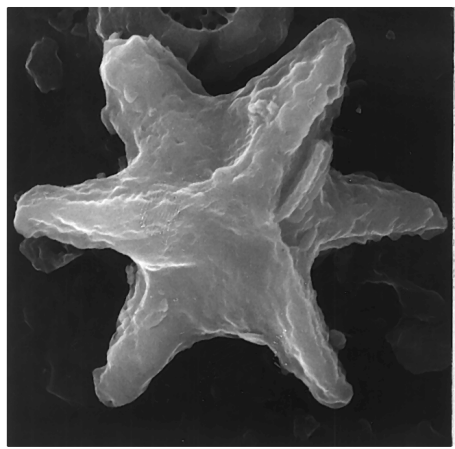

4a

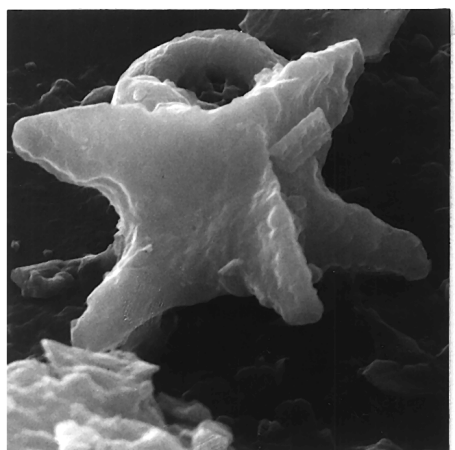

4b

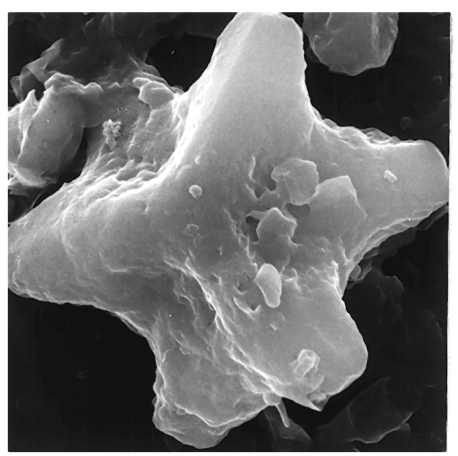

$7 a$

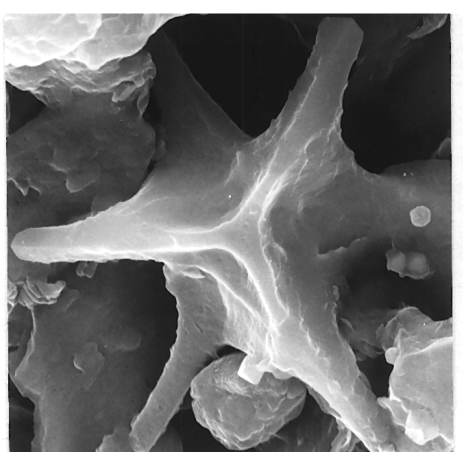

2

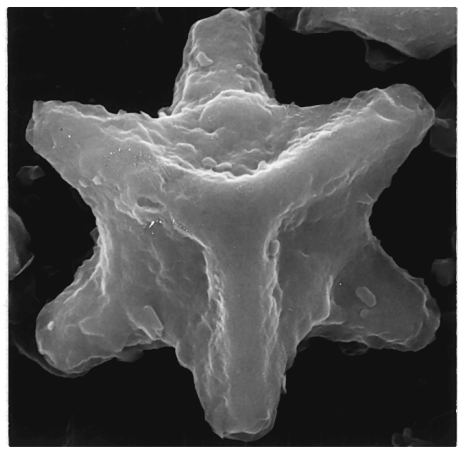

$5 a$

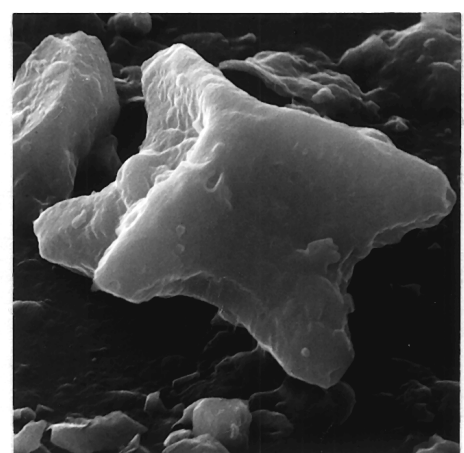

$5 b$

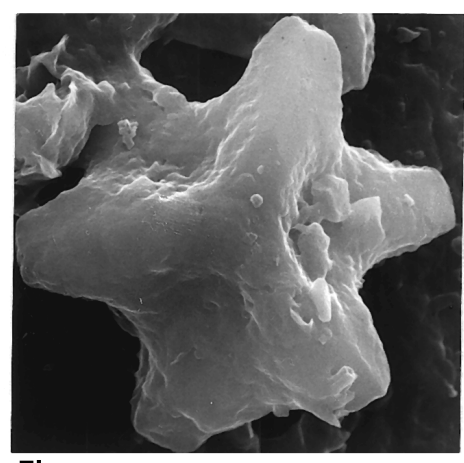

$7 b$

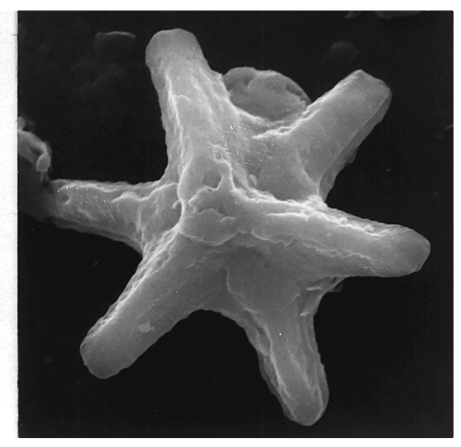

3a

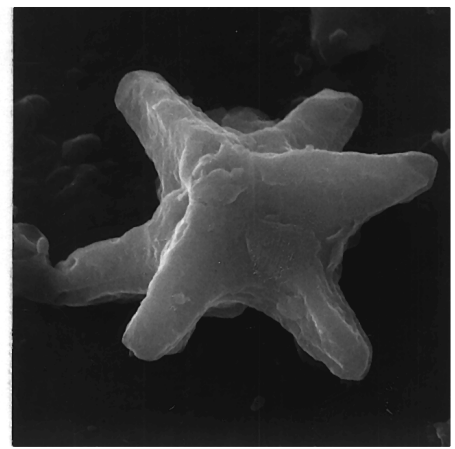

3b

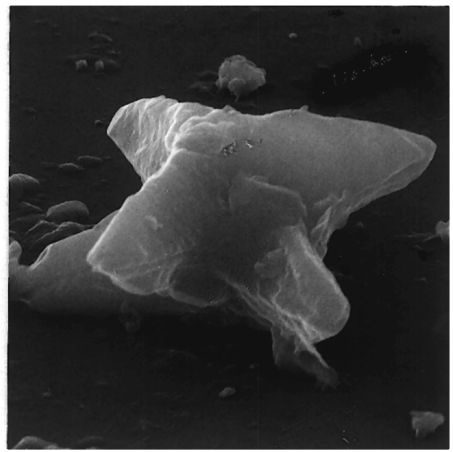

6

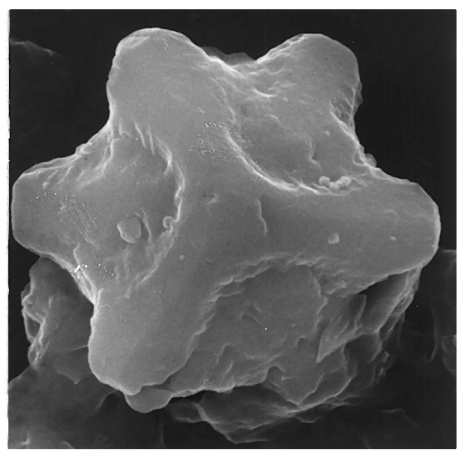

Plate 1. Island Beach Borehole 150X, New Jersey. All figures are SEM photomicrographs of Rhomboaster bramlettei. 1. 1066.9 ft, $4400 \times$, Zone NP10. 2. $1066.9 \mathrm{ft}, 4400 \times$, Zone NP10. 3a. $1020.9 \mathrm{ft}, 4400 \times$, Zone NP10. 3b. Same specimen, tilted and rotated view. 4a. $1027.9 \mathrm{ft}$, 5400×, Zone NP10. 4b. Same specimen, tilted and rotated view. 5a. $1027.9 \mathrm{ft}, 5400 \times$, Zone NP10. 5b. Same specimen, tilted and rotated view. 6. $1020.9 \mathrm{ft}, 4800 \times$, Zone NP10. 7a. $1020.9 \mathrm{ft}$, 5200×, Zone NP10. 7b. Same specimen, tilted and rotated view. 8. $1020.9 \mathrm{ft}, 6600 \times$, Zone NP10. 


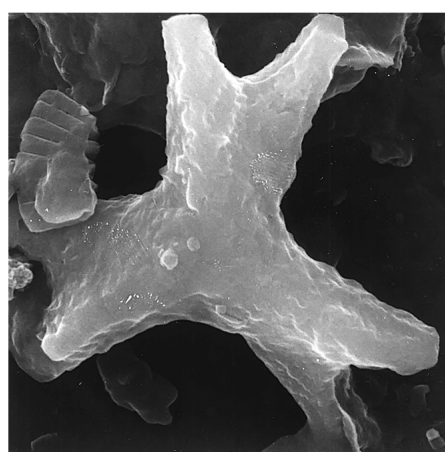

1a

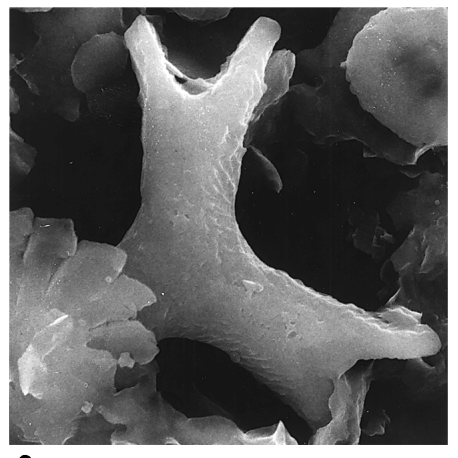

$3 a$

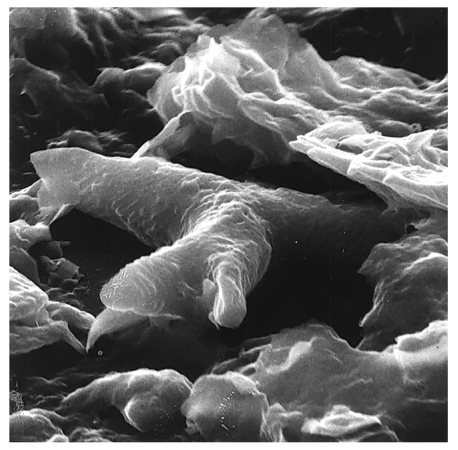

$3 b$

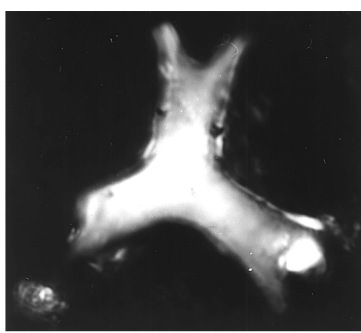

6

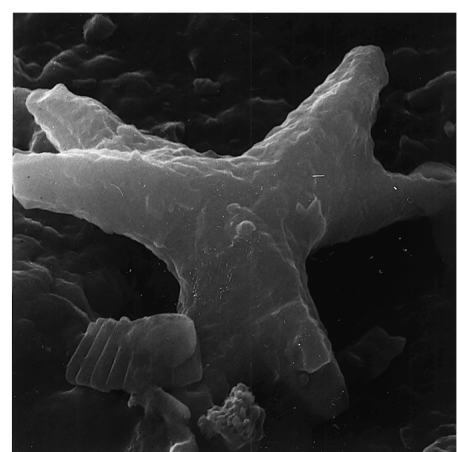

1b

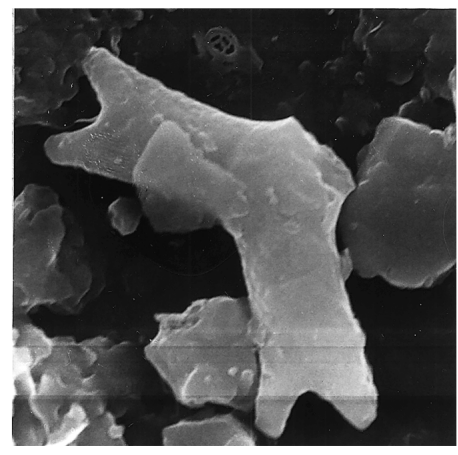

4a

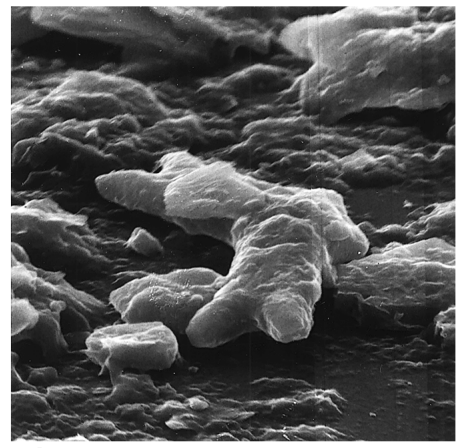

4b

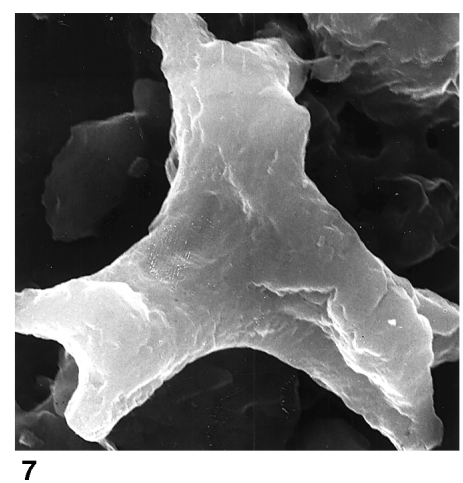

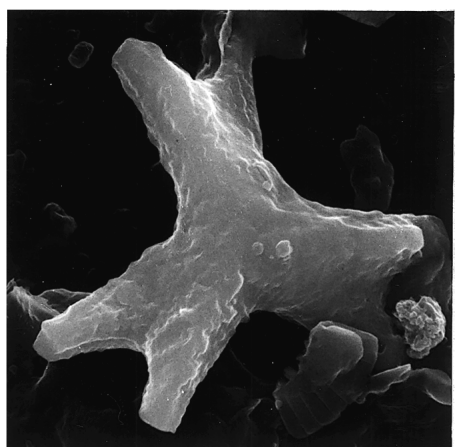

2a

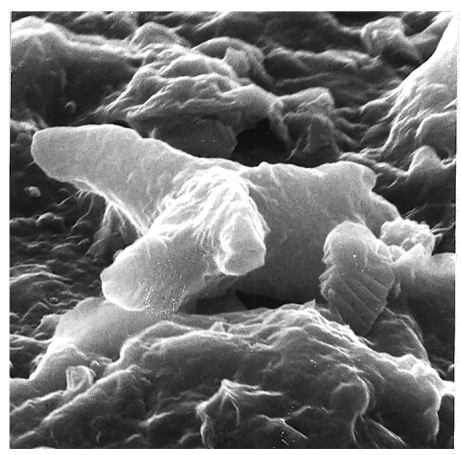

$2 b$

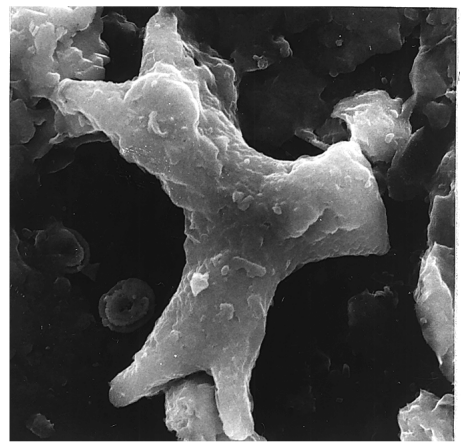

$5 a$

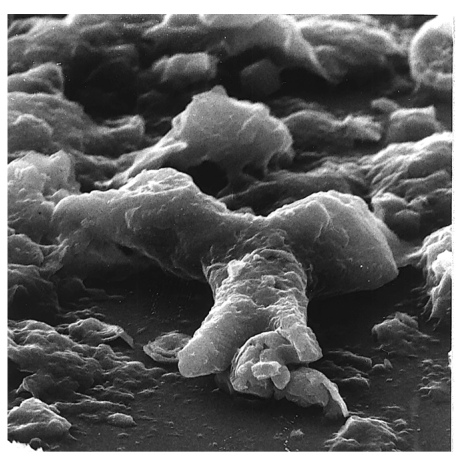

$5 b$

Plate 2. Island Beach Borehole 150X, New Jersey. All figures are SEM photomicrographs except Figure 6, which was photographed with cross-polarized light. Figures 1-2 are Rhomboaster contortus. 1a. 1018.9 ft, 6000×, Zone NP10. 1b. Same specimen, tilted view. 2a. $1018.9 \mathrm{ft}$, 5400×, Zone NP10. 2b. Same specimen, tilted view. Figures 3-7 are Rhomboaster digitalis n. comb. 3a. 1073.9 ft, 4000×, Zone NP10. 3b. Same specimen, tilted view. 4a. 1059.9 ft, $3000 \times$, Zone NP10. 4b. Same specimen, tilted view. 5a. 1073.9 ft, 2400× Zone NP10. 5b. Same specimen, tilted view. 6. 1075.2 ft, 2000×, Zone NP10. 7. 1073.9 ft, $4400 \times$, Zone NP10. 


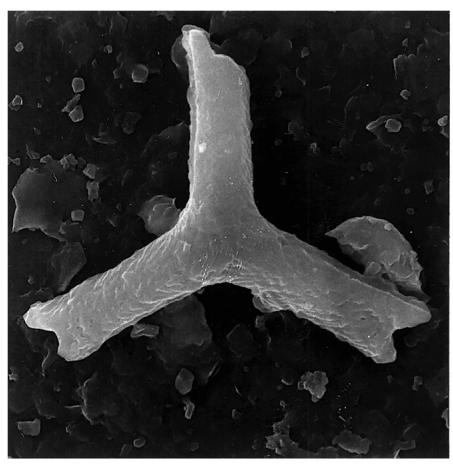

$1 \mathbf{a}$

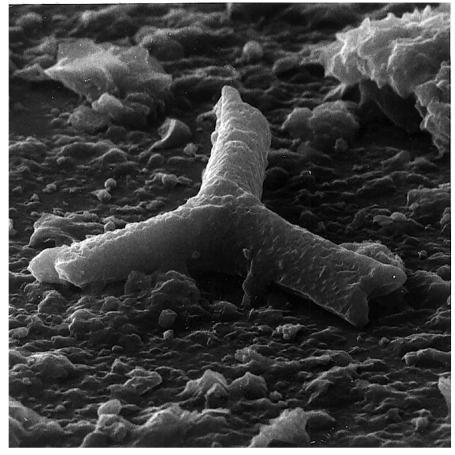

$1 b$

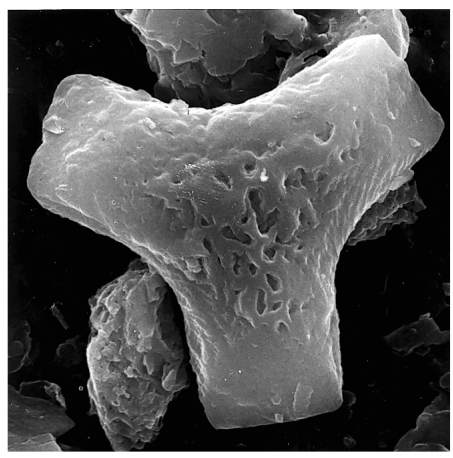

5

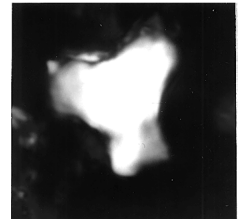

$8 a$

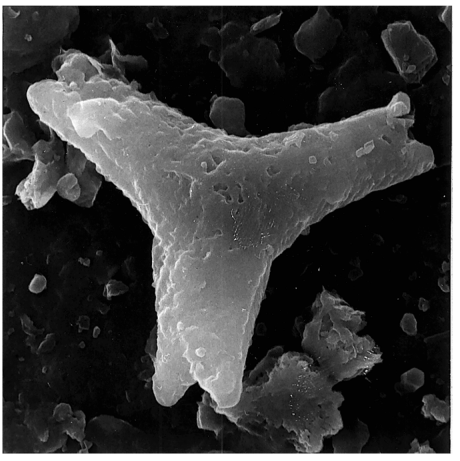

2a

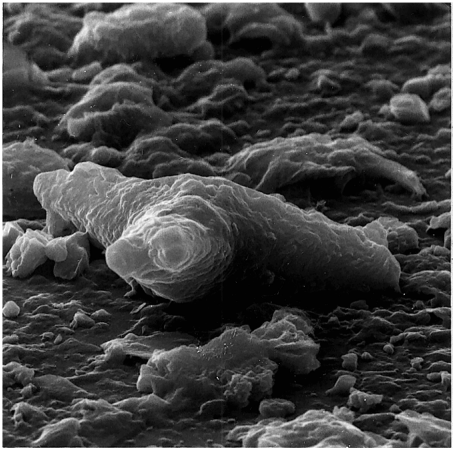

2b
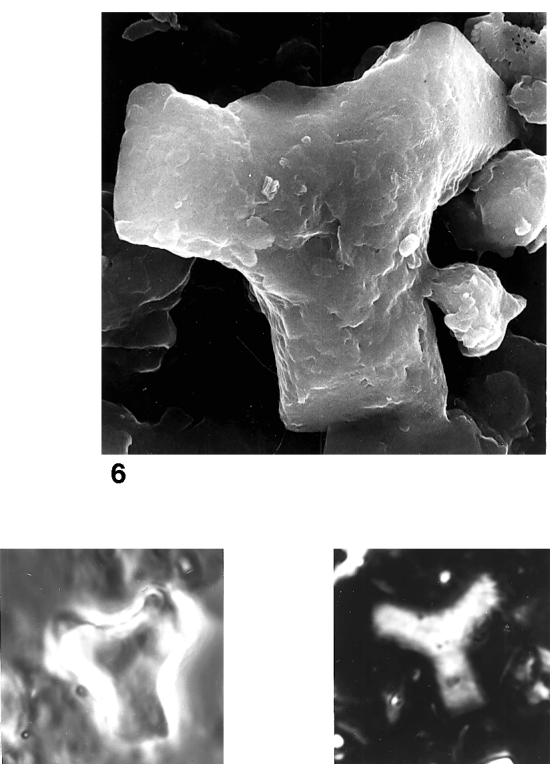

$8 b$

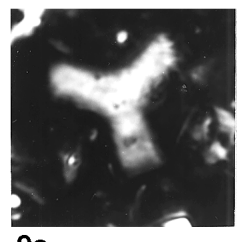

$9 \mathbf{a}$

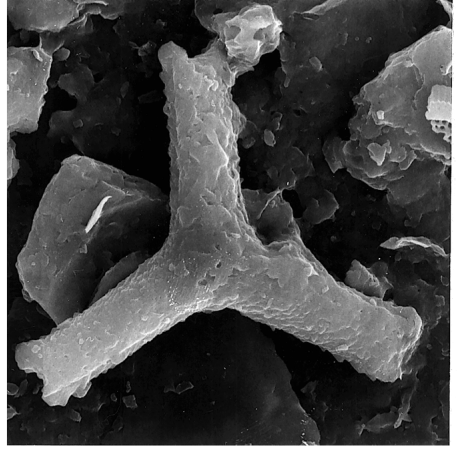

3

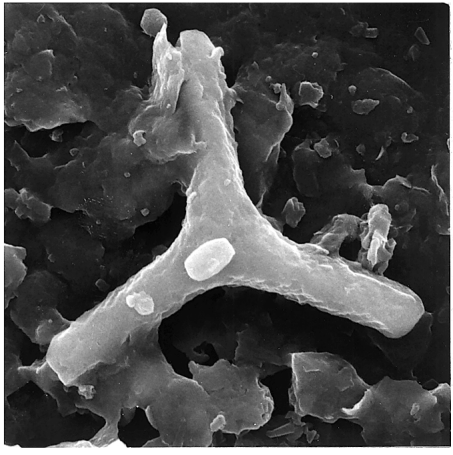

4
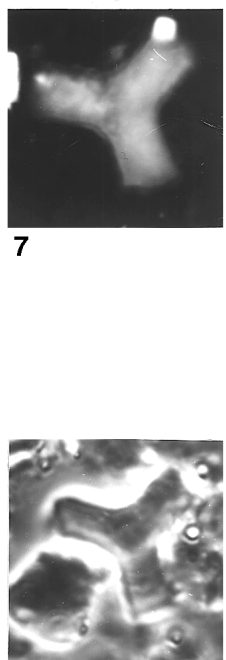

$9 b$

Plate 3. Island Beach Borehole 150X, New Jersey. Figures 1-6 are SEM photomicrographs. Figures 7, 8a, and 9a were photographed with cross-polarized light, and Figures $8 \mathrm{~b}$ and $9 \mathrm{~b}$ were photographed with phase-contrast light. Figures 1-4 are Rhomboaster orthostylus. 1a. 1016.9 ft, 2600×, Zone NP11. 1b. Same specimen, tilted view. 2a. 1016.9 ft, 3200×, Zone NP11. 2b. Same specimen, tilted view. 3. 1016.9 ft, 2400×, Zone NP11. 4. 1016.9 ft, 4000×, Zone NP11. Figures 5-9 are Rhomboaster weii n. sp. 5. $1016.9 \mathrm{ft}, 4400 \times$, Zone NP11, holotype. 6. $1073.9 \mathrm{ft}, 4000 \times$, Zone NP10, paratype. 7. 1075.2 ft, 2000×, Zone NP10. 8a. 1075.2 ft, 2000×, Zone NP10. 8b. Same specimen, phase contrast. 9a. 1075.2 ft, 2000×, Zone NP10. 9b. Same specimen, phase contrast. 


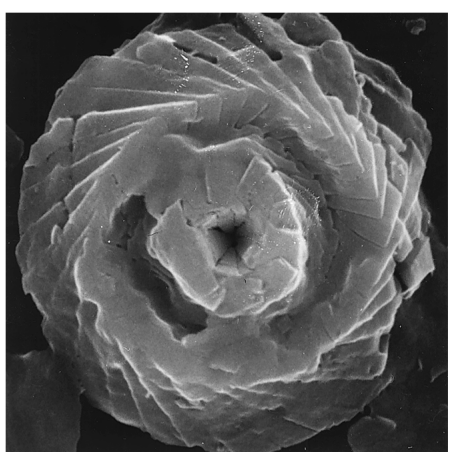

1a

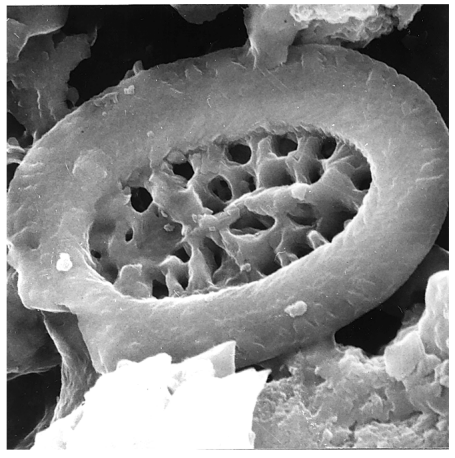

3

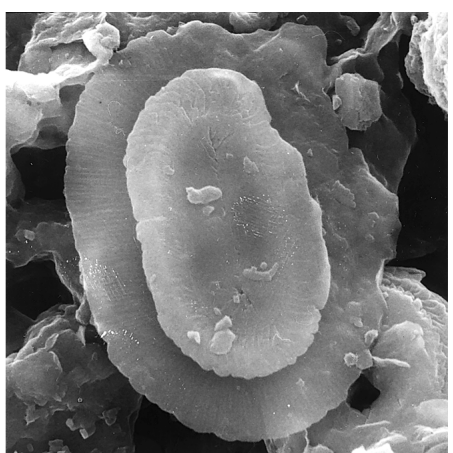

6

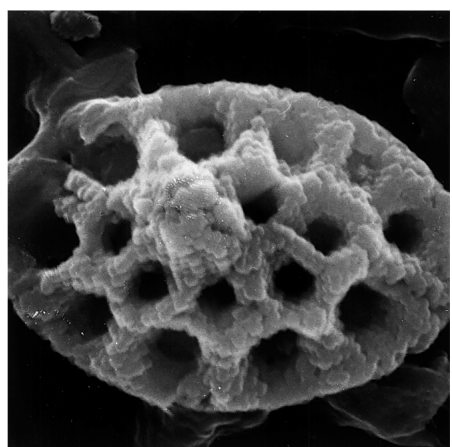

9

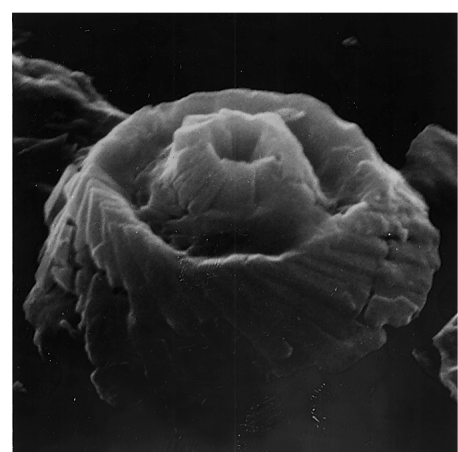

1b

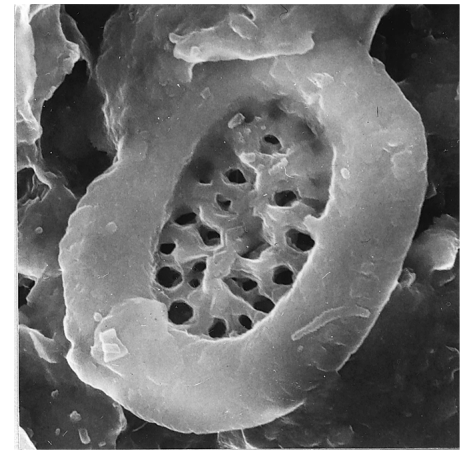

4

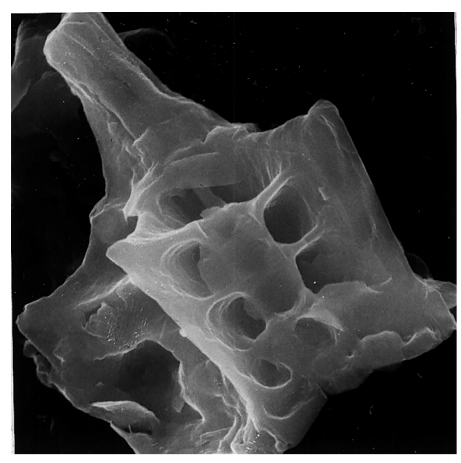

7

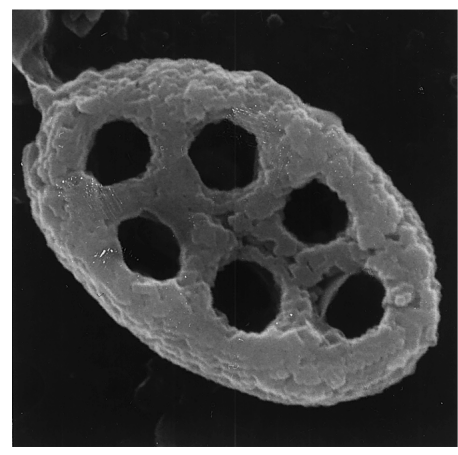

10

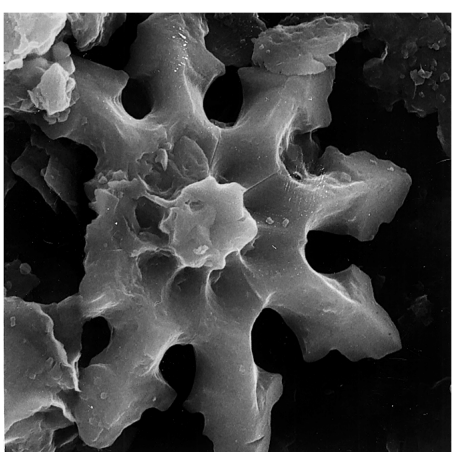

2

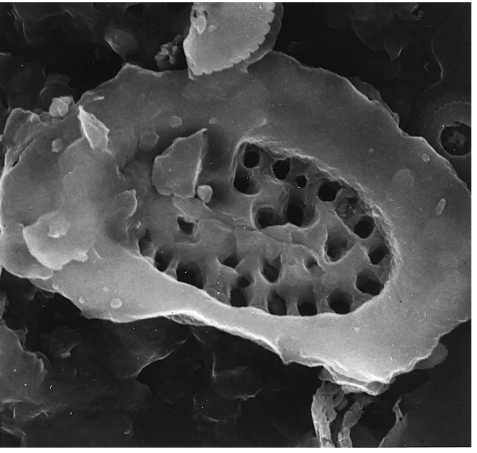

5

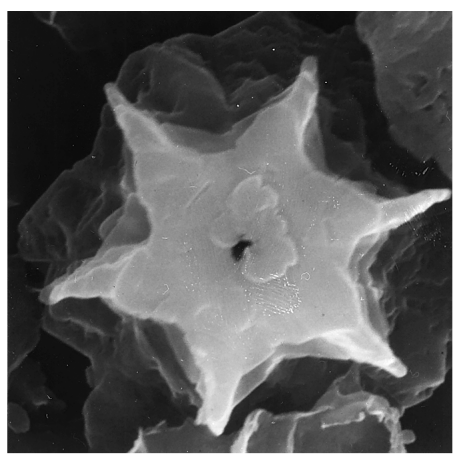

8

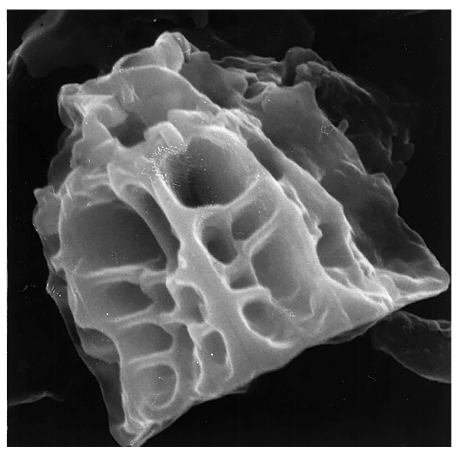

11

Plate 4. Island Beach Borehole 150X, New Jersey. All figures are SEM photomicrographs. 1a. Cyclagelosphaera prima, 1073.9 ft, 10,000×, Zone NP10. 1b. Same specimen, tilted view. 2. Discoaster limbatus, $1023.8 \mathrm{ft}, 4000 \times$, Zone NP10. 3. Ellipsolithus sp., $1018.9 \mathrm{ft}, 4400 \times$, Zone NP10. 4. Ellipsolithus sp., 1018.9 $\mathrm{ft}, 4000 \times$, Zone NP10. 5. Ellipsolithus sp., $1018.9 \mathrm{ft}, 4400 \times$, Zone NP10. 6. Ellipsolithus macellus, $1023.8 \mathrm{ft}, 4800 \times$, Zone NP10. 7. Fasciculithus schaubii, $1059.9 \mathrm{ft}, 6000 \times$, Zone NP10. 8. Fasciculithus sidereus, $1073.9 \mathrm{ft}, 10,000 \times$, Zone NP10. 9. Holodiscolithus macroporus, 1018.9 ft, 12,000×, Zone NP10. 10. Holodiscolithus solidus, $1020.9 \mathrm{ft}, 10,000 \times$, Zone NP10. 11. Fasciculithus thomasii, $1023.8 \mathrm{ft}, 8600 \times$, Zone NP10. 


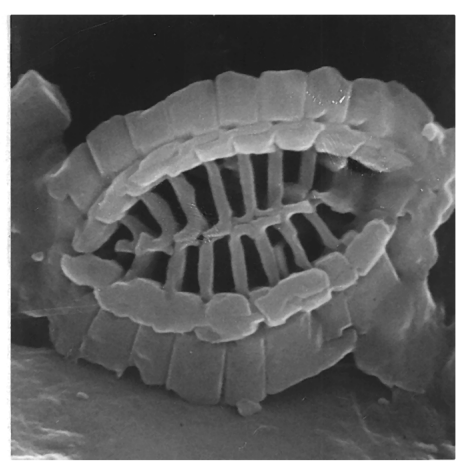

1

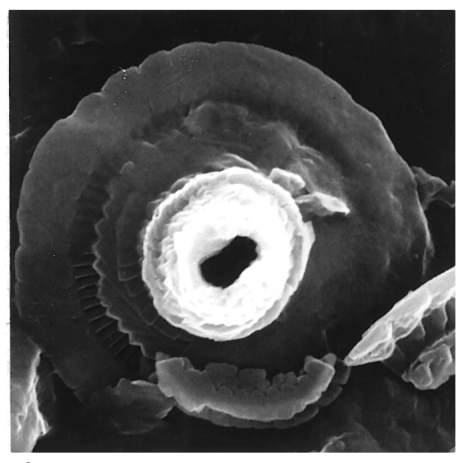

4

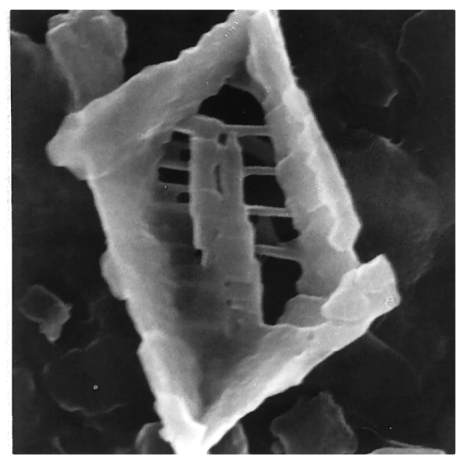

7

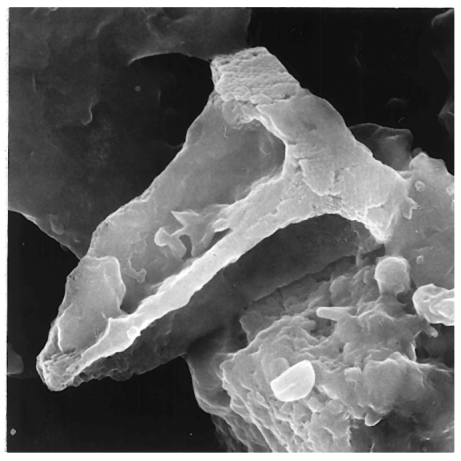

10

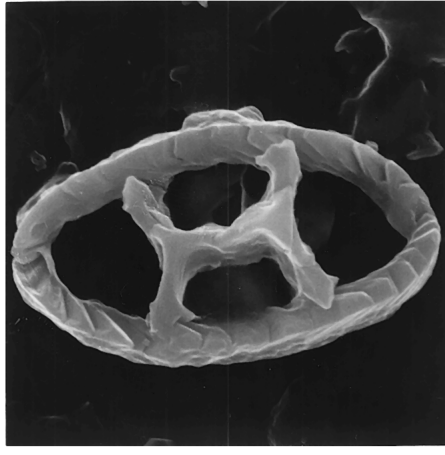

2

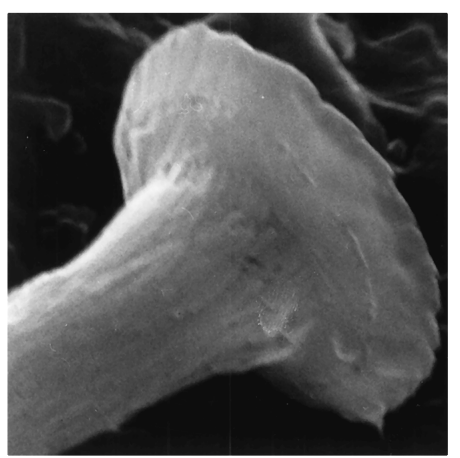

5

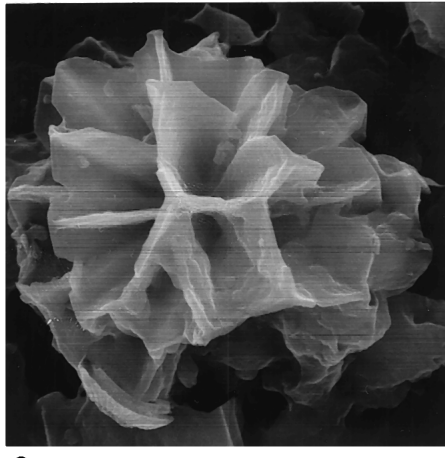

8

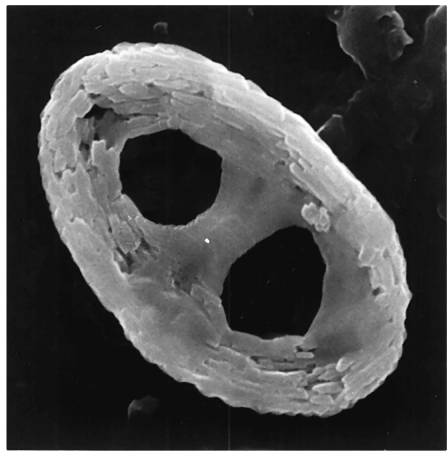

11

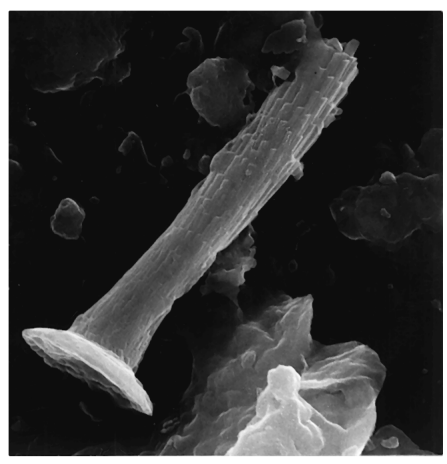

3

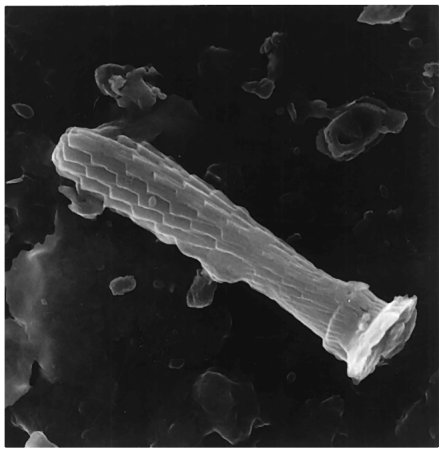

6

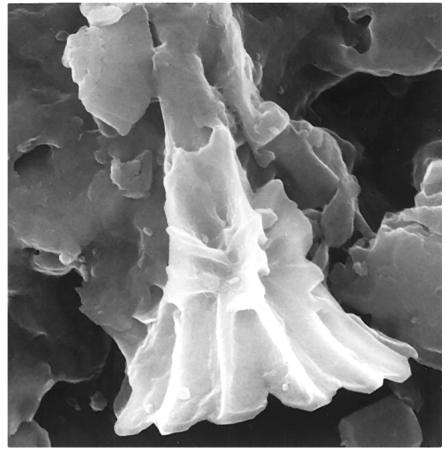

9

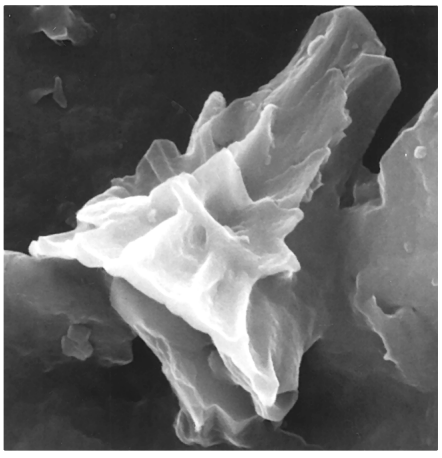

12

Plate 5. Island Beach Borehole 150X, New Jersey. All figures are SEM photomicrographs. 1. Hornibrookina arca, 1020.9 ft, 10,000×, Zone NP10. 2. Neococcolithes dubius, $1018.9 \mathrm{ft}, 7200 \times$, Zone NP10. 3. Blackites herculesii n. comb., $1018.9 \mathrm{ft}, 4000 \times$, Zone NP10. 4. Blackites herculesii $\mathrm{n}$. comb., $1018.9 \mathrm{ft}$, 10,000×, Zone NP10. 5. Blackites herculesii n. comb., 1018.9 ft, 12,000×, Zone NP10. 6. Blackites herculesii n. comb., 1059.9 ft, $4400 \times$, Zone NP10. 7. Scapholithus apertus, $1023.8 \mathrm{ft}, 12,000 \times$, Zone NP10. 8. Sphenolithus primus, $1018.9 \mathrm{ft}, 4800 \times$, Zone NP10. 9. Sphenolithus editus, $1018.9 \mathrm{ft}, 5400 \times$, Zone NP10. 10. Zygrhablithus bijugatus, $1018.9 \mathrm{ft}, 6000 \times$, Zone NP10. 11. Transversopontis pulcher, $1018.9 \mathrm{ft}, 7200 \times$, Zone NP. 12. Sphenolithus editus, $1018.9 \mathrm{ft}$, $10,000 \times$, Zone NP10. 